\title{
Elastic and electrical properties and permeability of serpentinites from Atlantis Massif, Mid-Atlantic Ridge
}

\author{
by \\ Ismael Falcon-Suarez ${ }^{*}$ \\ Gaye Bayrakci \\ Tim A. Minshull ${ }^{2}$ \\ North J. Laurence ${ }^{1}$ \\ Angus I. Best ${ }^{1}$ \\ Stéphane Rouméjon ${ }^{3}$ \\ \& \\ IODP Expedition 357 Science Party ${ }^{4}$
}

(1) National Oceanography Centre, University of Southampton Waterfront Campus, European Way, Southampton, SO14 3ZH, United Kingdom.

(2) Ocean and Earth Science, National Oceanography Centre Southampton. University of Southampton, European Way, Southampton, SO14 3ZH, UK

(3) ETH, Institute of Geochemistry and Petrology, Sonneggstrasse 5, Zürich, 8092, Switzerland

(4) http://www.eso.ecord.org/expeditions/357/357participants.php

*Corresponding author: National Oceanography Centre, University of Southampton Waterfront Campus, European Way, Southampton, SO14 3ZH, UK.

Phone: +44 (0)23 80596666 Office: 786/15 email: isfalc@noc.ac.uk

\section{History dates:}

$11^{\text {th }}$ January 2017 , submitted to GJl;

$22^{\text {nd }}$ March 2017, submitted reviewed version (R1) to GJI;

$20^{\text {th }}$ July submitted reviewed version (R2) to GJI; accepted $2^{\text {nd }}$ August 2017 


\section{Abstract}

Serpentinized peridotites co-exist with mafic rocks in a variety of marine environments including subduction zones, continental rifts and mid-ocean ridges. Remote geophysical methods are crucial to distinguish between them and improve the understanding of the tectonic, magmatic and metamorphic history of the oceanic crust. But, serpentinite peridotites exhibit a wide range of physical properties that complicate such a distinction. We analyzed the ultrasonic P- and S-wave velocities $\left(V_{p}, V_{s}\right)$ and their respective attenuation $\left(Q_{p}{ }^{-1}, Q_{s}{ }^{-1}\right)$, electrical resistivity and permeability of four serpentinized peridotite samples from the southern wall of the Atlantis Massif, Mid-Atlantic Ridge, collected during International Ocean Discovery Program (IODP) Expedition 357. The measurements were taken over a range of loading-unloading stress paths (5 - 45 MPa), using $\sim 1.7 \mathrm{~cm}$ length, $5 \mathrm{~cm}$ diameter samples horizontally extracted from the original cores drilled on the seafloor. The measured parameters showed variable degrees of stress dependence, but followed similar trends. $V_{p}, V_{s}$, resistivity and permeability show good inter-correlations, while relationships that included $Q_{p}{ }^{-1}$ and $Q_{s}^{-1}$ are less clear. Resistivity showed high contrast between highly serpentinized ultramafic matrix (>50 $\Omega \mathrm{m}$ ) and mechanically/geochemically altered (magmatic/hydrothermal-driven alteration) domains $(<20 \Omega \mathrm{m})$. This information together with the elastic constants $\left(\mathrm{V}_{\mathrm{p}} / \mathrm{V}_{\mathrm{s}}\right.$ ratio and bulk moduli) of the samples allowed us to infer useful information about the degree of serpentinization and the alteration state of the rock, contrasted by petrographic analysis. This study shows the potential of combining seismic techniques and controlled source electromagnetic surveys for understanding tectono-magmatic processes and fluid pathways in hydrothermal systems. 
Key words: Electrical properties, permeability and porosity, acoustic properties, mid-ocean ridge processes 


\section{Introduction}

Serpentinization is a low to intermediate temperature $\left(100\right.$ to $\left.700^{\circ} \mathrm{C}\right)$ metamorphic process resulting from reaction of olivine (or olivine and pyroxene) with water (Mcdonald and Fyfe 1985), which affects mafic and ultramafic rocks.

Serpentinization involves exothermic reactions and is associated with an increase in volume (up to $40 \%$ ) (Macdonald and Fyfe, 1985) and a decrease in density (from 3.3 to $2.6 \mathrm{~g} / \mathrm{cm}^{3}$ ) (Christensen, 2004) that modifies the rheology of oceanic crust and mantle rocks. It can lead to a strength reduction of up to $30 \%$ with respect to unaltered olivine-bearing rocks (Escartín and Cannat, 1999). This softening effect can drive mechanical decoupling and have a strong impact on the evolution of active tectonic zones (Guillot et al., 2015).

Serpentinized peridotites co-exist with altered or fresh mafic rocks (e.g., Blackman et al., 2011) in a variety of marine environments (Bayrakci et al., 2016). Distinguishing between mafic and ultra-mafic lithologies is critical for understanding the tectonic, magmatic and metamorphic history of the oceanic floor. However, identifying them using solely remote geophysical methods, such as gravity or seismic surveys, is challenging (Miller and Christensen, 1997). In such cases, both rock types have similar physical properties, for example density and seismic velocity (compressional, $\mathrm{V}_{\mathrm{p}}$, or shear, $\mathrm{V}_{\mathrm{s}}$ ) (Carlson and Miller, 2004). Wide-angle seismic studies allow the degree of serpentinization to be estimated using an empirical relationship between seismic velocities and water content (Carlson and Miller, 2003). Also, the $V_{p}$ to $V_{s}$ ratio and the P-wave anisotropy (ranging from $15 \%$ to $1 \%$ ) have been demonstrated to be good indicators of serpentinization (Horen et al., 1996). However, in situ measurement of the $V_{p}$ to $V_{s}$ ratio is limited by the commonly low amplitude of S-waves in marine wide-angle seismic data. Furthermore, when the 
degree of serpentinization is between $20-40 \%$, the P-and S-wave velocities and the density of partially serpentinized peridotite remain in the same range as those of fresh or altered mafic rocks (Iturrino et al., 1991).

Electrical resistivity is an alternative parameter that may allow low-resistivity serpentinized peridotite to be distinguished from those dominated by fresh or altered mafic rocks (Evans et al., 2010, Minshull, 2009), with resistivity values potentially several orders of magnitude higher in the latter (Stesky and Brace, 1973). However, electrical resistivity depends on the physico-chemical properties of the pore fluid (pressure, temperature and salinity) as well as the solid rock matrix, so inferring lithological variations from resistivity variations may result in misleading interpretations. In addition, very few studies can be found in the literature addressing electrical properties of serpentinite core specimens (Popp and Kern, 1993, Stesky and Brace, 1973), and there are only a few analyses using millimetric sized samples (Guo et al., 2011, Reynard et al., 2011, Xie et al., 2002).

Estimates of variations in the degree of serpentinization can provide valuable information about fluid flow patterns in hydrothermal systems and tectonomagmatic processes that lead to lithospheric heterogeneities and detachment faulting (Guillot et al., 2015, Früh-Green et al., 2016), including brittle processes that control the flux of sea water into the Earth (Bayrakci et al., 2016). The connectivity of a porous rock (i.e., effective porosity) determines how easily water passes through the rock (i.e., permeability), and also controls the electrical properties. Hence, the electrical resistivity and permeability of a rock are likely to be correlated. Oceanic crustal rocks are expected to have low porosity and permeability, but these parameters depend on the precise lithology and degree of alteration or deformation (Manning and 
Ingebritsen, 1999); overall, permeability is a fracture-dependent parameter in most geological contexts.

Serpentinites have been recovered at continental rifted margins (e.g., the west Iberia margin (Boillot et al., 1987, Whitmarsh et al., 1998)), at mid ocean ridges (e.g., MARK area near $23^{\circ} \mathrm{N}$ and the Kane Fracture Zone (Cannat et al., 1995)), in subduction zones (e.g., Izu-Bonin-Mariana forearc region (Fryer et al., 1990)) and continental strike-slip faults (Hirth and Guillot, 2013, Moore et al., 1996). During IODP Expedition 357, shallow mantle sequences were recovered along the southern wall of the Atlantis Massif on the Mid-Atlantic Ridge $30^{\circ} \mathrm{N}$ (Fig. 1). The recovered cores include intervals of harzburgite intruded by varying proportions of dunites, pyroxenite and gabbroic rocks, locally with a high degree of serpentinization. Atlantis Massif is a young (<2Myr; Grimes et al. (2008)) oceanic core complex typical of a slow spreading ocean lithospheric accretion environment, exposed by a major fault system (Blackman et al., 1998, Blackman et al., 2011, Karson et al., 2006, Schroeder and John, 2004). Near the top of the faulted escarpment of the southern ridge, the Lost City Hydrothermal Field (LCHF) lies on a down-dropped terrace at 750-800 m water depth and represents a hydrothermal vent system associated with active serpentinization (Denny et al., 2015, Früh-Green et al., 2003, Kelley et al., 2001, Kelley et al., 2005).

In this study, we measured the $\mathrm{P}$ and $\mathrm{S}$ wave velocities and their respective attenuations, the electrical resistivity (including 3D tomography), and the permeability of four serpentine-bearing ultramafic samples from the southern wall of the Atlantis Massif collected during IODP Expedition 357 (Früh-Green et al., 2016). These parameters were measured over a range of differential pressures that replicate 
shallow confining conditions beneath the seafloor (down to $~ 2 \mathrm{~km}$ depth), including loading and unloading states of stress.

\section{Materials and Methods}

\subsection{Description of rock samples}

The cores sampled in this study were acquired with the British Geological Survey's seabed Rockdrill 2 (RD2) (Früh-Green et al., 2016). The cores are approximately $6.2 \mathrm{~cm}$ in diameter and were bisected along their axes for geophysical and geochemical analysis and subsampling. Using vertical core-halves from different drilling sites across the Atlantis Massif, $5 \mathrm{~cm}$ diameter samples were cored horizontally, cut and their ends ground flat, resulting in 1.6 to $1.7 \mathrm{~cm}$ length samples. Among them, four samples were selected to perform this study based on their different textures observed at the visual scale, covering foliated, massive and fractured samples.

The samples investigated include ultramafic rocks with high degrees of serpentinization from the eastern (Hole M0068B, sample S1) and central (Hole M0076B, samples S2 and S3, and Hole M0069A, sample S4) areas collected during IODP Expedition 357 (Früh-Green et al., 2016) (Table 1). After the experiment, thin sections, oriented parallel to the horizontal plane, were manufactured from the central part of the samples to conduct petrographic analyses.

The samples were saturated in degassed $35 \mathrm{~g} \mathrm{~L}-1 \mathrm{NaCl}-$ brine (electrical resistivity $\sim 0.19 \Omega \mathrm{m}$ ) via water imbibition in a vacuum vessel (Amalokwu et al., 2014). First, the samples were oven-dried $\left(\right.$ at $\left.60^{\circ} \mathrm{C}\right)$ and kept under vacuum inside a pressure vessel for two days. Then, brine was supplied and pore pressure gradually increased up to $5 \mathrm{MPa}$, and held constant during 16 days before testing. Effective 
porosity $(\phi)$, estimated from the pore volume (as wet-dry weight difference after tests) to bulk volume ratio, bulk density $\left(\rho_{b}\right)$ and grains density $\left(\rho_{s}\right)$ are shown in Table 1. Furthermore, we display a preliminary estimation of the serpentinite content (serp), using the empirical relationship proposed by Miller and Christensen (1997), as follows:

$$
\rho=3.3-0.785 \cdot \operatorname{serp}
$$

This relationship was performed on very low porosity samples $(\phi<0.025)$. We have used the grain density as $\rho$ instead of the bulk density, to avoid overestimations of serpentinization associated with the high porosity exhibited for samples S2 and S5 (and to a lesser extent to S4), likely related to stress-release induced microfracturing.

\subsection{Experimental setup}

Measurements were carried out using the high-pressure, room-temperature multi-fluid experimental rig recently developed at the National Oceanography Centre in Southampton (Falcon-Suarez et al., 2016) (Fig. 2). The system allows the simultaneous measurement of the hydromechanical properties and geophysical signatures of $5 \mathrm{~cm}$ diameter, up to $2.5 \mathrm{~cm}$ length rock samples.

The rig is designed around a triaxial vessel, where the samples can be hosted and confined (axially, $\sigma_{1}$, and radially, $\sigma_{3}$, independently) with the aid of highpressure, high-accuracy pumping controllers (ISCO Teledyn model EX100D; pore and confining pressure controllers on Fig. 2). Inside the vessel, a rubber sleeve prevents the contact between the confining mineral oil and the sample and is equipped with 16 electrodes to obtain electrical resistivity (hereafter denoted as resistivity) measurements. Axially, the confining pressure is applied through two stainless-steel platens designed to host ultrasonic sensors to measure P-and S- 
wave velocities and their respective attenuations. The ultrasonic properties are determined using the pulse echo technique (Best et al., 2007, McCann and Sothcott, 1992), which requires a material of well-defined acoustic impedance and low energy loss between the sample and the sensors (see Fig. 2). In our case, we use polyether ether ketone (PEEK) buffer rods that provide a reliable delay path to enable the identification of top/base sample reflections for calculating wave velocities and attenuations. The buffer rods implement axial pathways (inlet and outlet ports) to conduct the pore fluid through the sample.

The fluid is controlled by a second dual EX100D system: one cylinder to deliver water (brine) upstream of the sample, the other acting as backpressure (receiver) downstream. Additionally, two piezo-resistive pressure transmitters (Keller model PA-33X; PT, Fig. 2) are inserted upstream and downstream in the hydraulic system to accurately measure pressure and temperature changes; they were located close to the axial platens to be representative of the actual conditions inside the vessel. The high-pressure hydraulic network used to drive the fluid into the sample was divided into different pipe-sections by high pressure valves, to satisfy the requirements of the experimental procedures applied in this study to measure the permeability (see below).

\subsection{Geophysical measurements}

As previously introduced, ultrasonic $\mathrm{P}$ - and S-wave velocities $\left(V_{p}\right.$ and $\left.V_{s}\right)$ and attenuations (inverse quality factors $Q_{p}^{-1}$ and $Q_{s}^{-1}$ ) were measured using the pulseecho technique. The velocity precision is $\pm 0.1 \%$ while the accuracy is $\pm 0.3 \%$ ( $95 \%$ confidence), while the attenuation accuracy is $\pm 0.1 \mathrm{~dB} / \mathrm{cm}$ (Best, 1992), for the transducers used in this study. 
The sleeve inside the triaxial cell was equipped with an array of 16 electrodes distributed in two rings of eight around the core. The electrodes were connected to an electrical resistivity tomography data acquisition system designed and developed at the NOC, Southampton (North et al., 2013). The system uses a tetra-polar electrode configuration to minimize electrode polarization artefacts. 208 individual tetra-polar measurements using various permutations of current injection and potential difference sensing electrode pairs are acquired during each acquisition run. These data are then inverted using software based upon the EIDORS (Andy and William, 2006) MATLAB toolkit for a uniform/homogeneous isotropic resistivity and heterogeneous isotropic resistivity distribution. Both inversion schemes employ a finite element forward model of the sample and electrodes.

The 3D isotropic electrical resistivity distribution within the sample was obtained using the EIDORS based absolute Gauss Newton solver. For the resistivity distributions shown in this work, we set the EIDORS Gauss Newton solver hyperparameter value to 107 - that optimizes minimization of residuals, which controls the smoothness of the solution, used five iterations and set the minimum and maximum resistivity to 0.001 and $100 \Omega \mathrm{m}$, respectively. The unstructured tetrahedral mesh used in the forward model for both the homogeneous and heterogeneous inversions had approximately 8000 elements and was a compromise between computation time and resolution. The mesh used was considerably finer adjacent to the electrodes, where sensitivity is highest, and lower toward the center of the model where larger elements have less effect on the residuals obtained during data inversion. Under typical operating conditions the resistivity measurement error is $\sim 5 \%$ (at frequencies $1-500 \mathrm{~Hz}$ ) for samples with homogeneous resistivity in the range 1-100 $\Omega \mathrm{m}$. 


\subsection{Permeability determinations}

Ultramafic rocks and serpentinites typically have low permeabilities, commonly below $10^{-17} \mathrm{~m}^{2}$ (Fisher, 1998), although fractures may lead to preferential flow paths and increased permeability (Manning and Ingebritsen, 1999). In this study, we dealt with variable situations, combining fractured and a priori massive, or non-openfractured, samples depending on the rock matrix, but also on the applied differential stress.

The most widespread method to determine core flow-throw permeability in high to moderate permeability media $\left(>10^{-16} \mathrm{~m}^{2}\right)$ is steady state flow (SSF). SSF is based on Darcy's law which calculates permeability, $\mathrm{k}\left(\mathrm{m}^{2}\right)$, from the volumetric flow rate, $\mathrm{Q}$ $\left(\mathrm{m}^{3} \mathrm{~s}^{-1}\right)$, for an upstream to downstream pressure difference, $\mathrm{P}_{\mathrm{u}}$ and $\mathrm{P}_{\mathrm{d}}(\mathrm{MPa})$, of a sample across a sectional area, $A\left(m^{2}\right)$, and length, $L(m)$, for a fluid dynamic viscosity, $\mu$ (Pa s), through the following expression:

$$
k=\frac{\mu L Q}{\left(P_{u}-P_{d}\right) A}
$$

Fracture compliance is expected during loading. Either because of stressinduced phenomena or due to the properties of the original matrix, the connectivity of the rock pores can be poor. Consequently, SSF becomes too time-consuming to implement. For low permeability media (below $10^{-17} \mathrm{~m}^{2}$ ), alternative methods based on transient states of the pore pressure may be used instead.

Brace et al. (1968) introduced the pulse decay method, which consists of inducing pore pressure disequilibria in the rock and determining the permeability through the evolution of pore pressure-time decay curves towards the original steady state. Also interesting is the pore pressure oscillation method, based on thermal diffusivity theory. It was originally presented by Kranz et al. (1990) and 
consists of generating an oscillatory pulse upstream of the sample to calculate the permeability based on the phase lag and amplitude attenuation of the signal downstream.

Based on the pulse decay method, Metwally and Sondergeld (2011) proposed an alternative technique in which an infinite volume is defined upstream: the pore pressure transmission method (PPT). In this method, after a sudden increase, $\mathrm{P}_{\mathrm{u}}$ is kept constant while the pressure downstream rises exponentially (Fig. 3). The mathematical expression theoretically describing this evolution is $\partial \mathrm{P}(\mathrm{t})=\mathrm{f}_{0} \mathrm{e}^{\alpha}$, where $f_{0}$ integrates the fluid storage capacities of the up- and downstream reservoirs. The permeability appears in the exponential part of the expression and can be directly linked to the experimental slope, $\alpha$, according to the following equation:

$$
\alpha=\left(\frac{-\theta^{2} \mathrm{k}}{\mu \mathrm{L}^{2} \mathrm{~B}_{\mathrm{f}} \phi_{\mathrm{e}}}\right),
$$

in which $B_{f}$ is the static (bulk) compressibility of the fluid within the downstream reservoir (pressure- and temperature-dependent parameter) and $\phi_{\mathrm{e}}$ the effective porosity of the sample. This expression neglects the effect of rock matrix compressibility, as it is commonly much lower than the compressibility of the fluid (Metwally and Sondergeld, 2011). The term $\theta$ combines the volumes of the up- and down-stream reservoirs $\left(V_{u}\right.$ and $V_{d}$, respectively) and the pore space of the sample $\left(P_{\mathrm{v}}\right)$ :

$$
\tan (\theta)=\frac{(\alpha+\gamma) \theta}{\theta^{2}-\alpha \gamma}
$$

being $\alpha=P_{v} V_{u}^{-1}$ and $\gamma=P_{v} V_{d}^{-1}$. But, as this method implies an infinite upstream reservoir capacity, then $\alpha=0$ and the expression above simplifies to $\tan (\theta)=\gamma \theta^{-1}$. So, for a given P-T conditions, this method is straightforwardly implemented provided 
that $V_{d}$ is known. This volume can be determined either from the inner dimensions of the pipe-transducer reservoir or from water-flooding of the experimental hydraulic network by monitoring the delivered water volume from the pumping controller.

The experiments were conducted at $19 \pm 0.2^{\circ} \mathrm{C}$. The compressibility of the brine not only depends on the pore pressure but also on the experimental reservoir features (materials involved in the experimental rig such us stainless steel pipes or PEEK - buffer rods). In this regard, as discussed by Brace et al. (1968), since compressibility and viscosity are pressure-dependent, the differential pressure $\left(P_{\text {diff }}\right)$ must be approximately constant through the sample during the test. Hence, the initial pore pressure gradient $\left(P_{0}\right)$ should be a few percent of the confining pressure (typically $<5 \%$ ) and not to be exceeded by more than $10 \%$ by either $\mathrm{P}_{\mathrm{u}}$ or $\mathrm{P}_{\mathrm{d}}$. Accordingly, in our tests, the initial pore pressure gradient was set at $0.5 \mathrm{MPa}$ for all measurements (i.e., $\mathrm{P}_{\mathrm{u}}=5.1 ; \mathrm{P}_{\mathrm{d}}=4.6 \mathrm{MPa}$, see below).

A simple calibration was carried out to account for the contribution of reservoir compressibility using the following expression (Metwally and Sondergeld, 2011):

$$
B_{f}=\frac{\Delta V / \Delta P}{V_{0}}
$$

where $V_{0}$ is the original reservoir volume. The calibration procedure included two steps. First, a stainless steel sample was hosted in the triaxial cell; then, the pressure downstream was incremented from 2 to $8 \mathrm{MPa}$, in $0.5 \mathrm{MPa}$ steps, while volume changes were recorded. The pipeline volume here includes V1 and V2 sections displayed in Fig. 3, so that the bulk compressibility is the contribution of both sections (i.e., $\mathrm{Bf}_{\mathrm{v} 1}+\mathrm{Bf}_{\mathrm{v} 2}$ ). Second, this procedure was then repeated but discounting the target sub-reservoir (i.e., V2, the volume between the sample and the first valve downstream), to obtain $\mathrm{Bf}_{\mathrm{V} 1}$. The difference between them, $\mathrm{Bf}_{\mathrm{V} 2}$, was 
estimated to be $5.8 \times 10^{-9} \mathrm{~Pa}^{-1}$, and was assumed to equal the bulk compressibility of the reservoir downstream under the P-T experimental conditions.

Our permeability measurements carry experimental uncertainties of $\sim 0.3 \%$ in the case of the SSF and $\sim 3 \%$ in the PPT.

\subsection{Experimental procedure}

Permeability (k), $\mathrm{V}_{\mathrm{p}}$ and $\mathrm{V}_{\mathrm{s}}, \mathrm{Q}_{\mathrm{p}}^{-1}$ and $\mathrm{Q}_{\mathrm{s}}^{-1}$, and resistivity were all measured for a set of differential pressures $\left(P_{\text {diff }}=P_{c}-P_{p}\right)$, by keeping constant the pore pressure $\left(P_{p}\right)$ at $5 \mathrm{MPa}$ while varying the confining pressure in a hydrostatic mode (i.e., $\left.P_{c}=\sigma_{1}=\sigma_{3}\right)$ from 10 to $50 \mathrm{MPa}$, in steps of $10 \mathrm{MPa}$, under drained conditions. Furthermore, to study potential hysteresis effects, two unloading measurements were made at confining pressures $30 \mathrm{MPa}$ and $10 \mathrm{MPa}$ to complete the differential stress path.

For every increasing/decreasing $P_{\text {diff }}$ step, we let the system stabilizes at $P_{p}=4.5 \mathrm{MPa}$, based on the continuous record of $P_{c}$ and $P_{p}$. Next, permeability is measured by SSF (S2 and S5) or PPT (S1 and S4). In the former case, after each permeability determination, the flow-through is stopped to let the $P_{p}$ equilibrates; in the latter, $P_{p}=5 \mathrm{MPa}$ is imposed upstream and a steady state is reached at the end of the permeability measurement. Finally, ultrasonic parameters and resistivity are measured immediately one after the others in order to obtain comparable values between them.

\section{Results}

\subsection{Petrographic analysis}


Thin section analysis reveals that the four considered peridotites show variable degrees of serpentinization and post-serpentinization alteration. In general, samples S1 and S4 show lower fracture densities than samples S2 and S5. Textures and mineralogical assemblages present in these samples are shown in Fig. 4, and the estimates of primary and secondary modal proportions can be found in Table 2 .

$\mathrm{S} 1$ is a metasomatised serpentinized harzburgite. Primary olivine was fully replaced by the magnetite-bearing lizardite-dominated mesh texture, while pyroxenes are variably altered to serpentine, tremolite, chlorite or talc. The original spinel has been partially altered to chromite and magnetite. The presence of chlorite ( \pm tremolite) domains might result from the alteration of clinopyroxene-rich magmatic veins. Pervasive silica metasomatism led to the almost complete replacement $(90 \%)$ of serpentine by talc, nevertheless preserving former magnetite concentrations of the mesh texture in centimeter-sized domains. The presence of magnetite contributes to increase the density of the solid particles above the expected value for talc ( 2785 $\mathrm{kg} \mathrm{m}^{-3}$ (Carlson and Miller, 2004)) up to $2833 \mathrm{~kg} \mathrm{~m}^{-3}$ (Table 1).

$\mathrm{S} 2$ is a typical serpentinized harzburgite, although close to a dunitic composition ( $5 \%$ pyroxene). Olivine is replaced by the magnetite-bearing lizarditedominated mesh texture (with a minor presence of chrysotile), and orthopyroxenes by bastite (serpentine) pseudomorphs. In addition to small serpentine veins, a late carbonate network overprints the mesh texture.

S4 is a serpentinized harzburgite in which the magnetite-bearing lizarditedominated mesh texture is partially replaced by a $\sim 1 \mathrm{~cm}$-wide domain composed of serpentine recrystallization textures (chrysotile and antigorite) and veins (chrysotile). Pyroxenes are altered to serpentine, tremolite, chlorite or talc. 
S5 is a serpentinized dunite. Primary olivine is fully replaced by the magnetitebearing mesh texture (lizardite \pm chrysotile).

Our estimates from the petrographic analysis agree relatively well with the preliminary serpentinized fraction we derived from the equation of Miller and Christensen (1997) for S2, S4 and S5 (Table 1). Such empirical relationships might not apply for $\mathrm{S} 1$, which is affected by post-serpentinization metasomatic alteration.

\subsection{Ultrasonic wave velocities and attenuations}

We observe similar ultrasonic responses between samples S1 and S4, and S2 and S5. In general, $\mathrm{S} 1$ and $\mathrm{S} 4$ exhibit $\mathrm{P}$ - and $\mathrm{S}$-wave velocities $\left(\mathrm{V}_{\mathrm{p}}\right.$ and $\left.\mathrm{V}_{\mathrm{s}}\right)$ that are $\sim 25 \%$ and $\sim 30 \%$ higher than S2 and S5 (Fig. 5). S1 shows the highest $V_{p}$, reaching $5 \mathrm{~km} \mathrm{~s}^{-1}$ at the maximum differential pressure $(45 \mathrm{MPa})$, while $V_{\mathrm{s}}$ sharply increases during the initial loading stages (below $25 \mathrm{MPa}$ ), remaining approximately constant at high stress stages and recovering its original value during unloading. $\$ 4$ shows little stress dependence, varying by less than $2 \%$ for both $V_{p}$ and $V_{s}$ during the test. S5 and S2 evolve similarly along the stress-path for $V_{p}$, with little hysteresis associated with unloading; for Vs, S5 increases with stress while S2 remains practically constant during the test.

Fig. 6 shows $\mathrm{P}$ - and S-wave attenuations, expressed as the inverse quality factors $Q_{p}{ }^{-1}$ and $Q_{s}{ }^{-1}$, respectively. $Q_{p}{ }^{-1}$ evolves inversely with increasing stress, being more pronounced in the cases of S2 and S5; S4 shows the contrary, reaching a maximum at $P_{\text {diff }}=45 \mathrm{MPa}$. Similar trends can be inferred from $\mathrm{Q}_{s}^{-1}$, but are less clear. S1 and S5 show more pronounced $Q_{s}{ }^{-1}$ stress-dependence, and inverse trends, than S2 and S4. 


\subsection{Electrical resistivity}

Resistivity (Fig. 7) is a stress-dependent parameter in the four cases, with similar values between S1 and S4, and between S2 and S5 as previously observed for the ultrasonic wave velocities. S1 and S4 show positive correlations with differential stress path (square correlation coefficient $R^{2}>0.8$ in all cases), with a maximum relative resistivity variation of $\sim 125 \%$ at $45 \mathrm{MPa}$ (from $\sim 40$ to $\sim 90 \Omega \mathrm{m}$ ). Both samples carry hysteresis, with resistivity increasing during the unloading stress path by $\sim 7 \%$ at $25 \mathrm{MPa}$ and up to $\sim 12 \%$ at $5 \mathrm{MPa}$. S5 shows the same trend as $\mathrm{S} 1$ and S4, but increasing only by $\sim 25 \%$ at $45 \mathrm{MPa}$ (from 8 to $10 \Omega \mathrm{m}$ ) with $\sim 2 \%$ hysteresis during unloading. S2 evolves similarly to S5 up to $35 \mathrm{MPa}$. At $45 \mathrm{MPa}$, it sharply increases by $\sim 220 \%$ and remains approximately constant, but still slightly increasing, regardless of the differential pressure.

3D electrical resistivity tomography provides further information regarding resistivity patterns inside the samples (Fig. 8). The three sections per sample show the resistivity distribution at different heights, being the central ones the most representative of the thin sections. We distinguish different resistivity domains that could be interpreted as: i) high resistivity regions, above $50 \Omega \mathrm{m}$, that might correspond to areas preferentially occupied by highly serpentinized harzburgite (matrix), based on previous results (Stesky and Brace, 1973); ii) low resistivity regions (up to $\sim 20 \Omega \mathrm{m}$ ) that can be associated with a pore-fluid conduction in a wellconnected fluid network (Evans et al., 2010) - particularly significant in the high porosity (visually fractured) samples S2 and S5. The tomography shows that S1 and S4 remain practically unaltered along the differential stress path. Therefore, the variations observed in the resistivity (Fig. 7) might be related to clogging of minor fluid paths during loading, which become partially reopened upon stress-release. S5 
shows an elastic behavior with very little resistivity variation across the sample. The increase of resistivity in S2 during the last loading step (45 MPa; Fig. 7) is also observed through the 3D tomography. The original fluid path network is substantially modified and remains approximately constant onwards, despite the unloading.

\subsection{Permeability}

Fig. 9 shows the results of permeability to water (brine) tests, performed on the four samples at the seven states of differential stress. Attempts were made to use the SSF method, but only successfully for S2 and S5; even so, the latter required high differential pressures to infer low flow rates at the limit of the pumping controller. As a result, $\mathrm{S} 5$ tests show increasing data scattering with the stress.

S1 and S4 showed low permeabilities similar to S5 and therefore the PPT method was used instead of SSF ( $R^{2}>0.99$ in all PPT tests). However, for the last stress stage on $\mathrm{S} 1$ ( $\mathrm{P}_{\text {diff }}=5 \mathrm{MPa}$, unloading), we applied both methods, with the aim of calibrating the bulk compressibility $\left(\mathrm{B}_{\mathrm{fv} 2}\right)$ by comparing SSF with PPT, considering SSF as the standard method (Falcon-Suarez et al., 2014). The difference between $\mathrm{B}_{\mathrm{fV} 2}$ calculated using eq. (5) $\left(5.8 \times 10^{-9} \mathrm{~Pa}^{-1}\right)$ and that inferred from the comparison between SSF and PPT $\left(7.1 \times 10^{-9} \mathrm{~Pa}^{-1}\right)$ falls within the error of the permeability measurements. The calculated $B_{f}$ was therefore adopted for the subsequent measurements.

Permeability decreases with stress for the four samples (Fig. 10). With the exception of S4, permeability drops by several orders of magnitude at the maximum differential stress $\left(\mathrm{S} 1\right.$, from $10^{-17}$ to $10^{-20} \mathrm{~m}^{2}$; $\mathrm{S} 2$, from $10^{-15}$ to $10^{-17} \mathrm{~m}^{2}$; $\mathrm{S} 5$, from $10^{-17}$ to $10^{-19} \mathrm{~m}^{2}$ ), which agrees with the quasi-exponential decay of permeability with depth reported by Manning and Ingebritsen (1999). S1 has the lowest permeability 
and shows significant hysteresis during the initial unloading (permeability remains approximately constant after decreasing $\mathrm{P}_{\text {diff }}$ to $25 \mathrm{MPa}$ ), although later it recovered up to its original value. S4 is less affected by stress changes, varying within the same order of magnitude $\left(10^{-19} \mathrm{~m}^{2}\right)$ along the differential stress path with slight hysteresis during unloading. S5 behaves practically elastically, but carries the highest uncertainty in the determinations (only this sample displays visible error bars). S2 is the most permeable sample and is also the less stress-dependent, remaining practically invariable during unloading.

\section{Discussion}

Stress-dependent relationships are observed for all the measured parameters. Large variations in electrical resistivity across the samples, together with permeability values several orders of magnitude higher than previously determined for serpentinites of $10^{-22}-10^{-19} \mathrm{~m}^{2}$ within the confining pressure range 5-50 MPa (Katayama et al., 2012, Kawano et al., 2011), lead us to suggest that fractures might be partially conditioning the measurements. Although rock composition has been emphasized as the fundamental property of serpentinites to be considered for seismologists to understand tectonic history (Christensen, 2004), the presence of fractures may also have a strong influence.

Fractures could ultimately mask compositional aspects when distinguishing between serpentinized and fresh ultramafic rocks with resistivities several orders of magnitude higher (Stesky and Brace, 1973), when the latter are highly fractured. However, the degree of serpentinization depends on the exposure of ultramafic rocks to fluid. Despite the fact that the degree of serpentinization is likely to be linked to the original connected fracture density of the rock, serpentinization is a volume- 
increasing process with the potential of filling, at least partially, the primary fractures. However, serpentinization itself may drive fracturing from low degrees of alteration (Plümper et al., 2012), when the strength of the rock suffers a sudden drop above $\sim 15 \%$ of serpentinization (Escartín et al., 2001), resulting in a higher vulnerability to deformation post-serpentinization. Likely, it applies to our four samples and further to all the samples collected during IODP Expedition 357, which have a high degree of serpentinization (Früh-Green et al., 2016; Früh-Green et al., 2017).

Deformation may lower the acoustic wave velocities of our four samples due to the presence of cracks/fractures in the matrix as observed in the thin sections, even though the cracks are expected to close during the early stages of loading (Asef and Najibi, 2013). For example, Brereton (1992) reported very little variation of the elastic wave velocities of oceanic basaltic rocks above $25 \mathrm{MPa}$ confining pressure. In our case, we observe that the different parameters measured tend to converge towards the maximum differential pressure (45 $\mathrm{MPa}$ ), particularly for $\mathrm{S} 1$ and $\mathrm{S} 4$, suggesting that the contribution of fractures above this value might be only significant for $\mathrm{S} 2$ and S5. The P- and S-wave velocities of S4 are associated with the observed lizarditechrysotile-dominant serpentinization (Fig. 4), which according to Guillot et al. (2015) can result in $V_{p}$ and $V_{s}$ below 4.6 and $2 \mathrm{~km} \mathrm{~s}^{-1}$, respectively; whilst for samples $S 2$ and S5, with similar compositions than S4, the wave velocities are far below these values, and even for those recognized for moderately altered oceanic crust samples at our experimental conditions (e.g., Brereton, 1992). We interpret the latter case as the interplay of microcracks and the minor secondary mineralization observed in the thin sections. On the other hand, S1 shows wave velocities similar to S4, which suggests that metasomatism post-serpentinization complicates compositional 
differentiation using only acoustic properties, i.e., in $\mathrm{S} 1$, talc has almost completely overprinted the original serpentinization textures.

\subsection{Relations between geophysical parameters and permeability}

The geophysical parameters and permeability measured show variable degrees of stress dependence. By cross-plotting results (Fig. 11), we identify some interesting relationships between the parameters. Further information about linear and exponential (only for permeability) correlation coefficients for the study variables can be found in the supplementary material (correlation matrix, Table S2).

Permeability (k) shows a good exponential correlation with ultrasonic velocity for each single sample $\left(R^{2}>0.89\right.$ and $>0.66$, for $V_{p}$ and $V_{s}$, respectively, decreasing to $R^{2}>0.56$ and $>0.58$ if considering all the samples), and correlates more weakly with attenuation $\left(Q_{p}{ }^{-1}\right.$ and $Q_{s}{ }^{-1}: R^{2}<0.6$, either for individuals or in all cases). However, similar k-Qp ${ }^{-1}$ trends can be distinguished for S2 and S5. S2 showed $Q_{p}{ }^{-1}$ higher than S5 by $\sim 85 \%$ (Fig. 6), which may indicate differences related to the fracture network such as orientation, shape or water content (Müller et al., 2010). Both samples are highly fractured, based on thin sections observations (Fig. 4), and have high porosities (S2 10\% and S5 12\%; see Table 1), resulting in higher permeabilities than for S1 and S4. Crack closure near the beginning of loading (up to $P_{\text {diff }}=5 \mathrm{MPa}$ ) could have been more effective in $\mathrm{S} 5$, leading to lower permeability and less variation of $Q_{p}^{-1}$ than $S 2$.

Drilling operations may have triggered micro-crack propagation and also reopened pre-existing fractures (Miller and Christensen, 1997; Früh-Green et al., 2017), originally filled by serpentinite due to enhanced fresh-peridotite surface exposure to water. The role played by the cracks/fractures can also be analyzed 
from other relationships between parameters. For example, the resistivitypermeability relationship is also (exponentially) very strong in each sample; but Fig. 11 also shows it depends on the value of resistivity: resistivity changes in low resistivity samples (S2 and S5) correlate with larger k variations than in those for high resistivity samples (S1 and S4). Thus, the samples with higher porosities change their permeability more rapidly with stress, because cracks improve the connectivity of the porous medium. This effect might be an issue if attempting to solely use resistivity to infer the degree of serpentinization. Combining controlled source electromagnetic (CSEM) surveys and seismic techniques could significantly improve the investigation of such contrasts.

Serpentinites have been found to have high resistivities (>1000 $\Omega \mathrm{m}$ ) at high temperature and high pressure conditions, due to dehydration (Popp and Kern, 1993, Reynard et al., 2011, Xie et al., 2002). However, our experiments have been carried out at relatively low PT and the values obtained remain below $100 \Omega \mathrm{m}$, which agree with the data reported by Stesky and Brace (1973) for similar PT conditions and pore fluid electrical conductivity $(\sim 0.19 \Omega \mathrm{m})$. Furthermore, variations within the samples are clearly distinguished from resistivity tomography, which are related to variable degrees of hydromechanical and geochemical alteration, as inferred from the thin sections (Fig. 4). Fig. 8 reveals that such resistivity variations become increasingly pronounced with increasing effective stress, providing further evidence for the role played by the fractures. We interpret these variations as corresponding to the contrast between highly serpentinized harzburgite matrix ( $>50$ $\Omega \mathrm{m}$ ) and partially (mechanically) altered matrix (<20 $\Omega \mathrm{m}$ ). Thus, S2, S4 and S5 have high degree of serpentinization and similar compositions (see Table 1 and Table 2), but S2 and S5 show the highest contrast between the two domains 
because both samples are highly mechanically altered (Fig. 4); S4 also has a wide range of resistivities above $20 \Omega \mathrm{m}$, but the variations decrease with increasing differential stress.

Low resistivity domains might also indicate the presence of vein filling secondary mineralization from hydrothermal alteration that might have occurred before, during or after serpentinization (Boschi et al., 2006). In this regard, metasomatic alteration to talc and/or amphibole-rich mineral assemblages has been identified in the detachment fault zone at the top of the Atlantis Massif along the southern wall (Boschi et al., 2006). We have observed post-serpentinization alteration that is particularly significant in samples S1 and S2, the former is affected by a metasomatic process (talc-dominant compact texture) while the latter shows a late carbonate network overprinting the lizardite-chrysotile mesh texture and partially filling fractures. However, the higher resistivity of S1, together with the higher porosity and permeability of S2, suggests that the connected fracture network particularly influences the resistivity distribution of the sample. In this regard, $S 1$ is compositionally different than the rest of the samples, but shows resistivity patterns similar to S4. This fact leads us to conclude that distinguishing between talcdominant and lizardite-chrysotile-dominant mafic and ultramafic rocks is very complicated using either resistivity, acoustic or permeability data, or even a combination of them, particularly when fractures are present.

Furthermore, highly conductive accessory minerals from the alteration of peridotite into serpentinite such as magnetite $\left(<10^{-5} \Omega \mathrm{m}\right)$, may affect the bulk resistivity of the rock when grains are interconnected (Evans et al., 2010). We recognize magnetite in our four samples, but it is forming aggregates or disseminated within lizardite-chrysotile-dominated mesh textures. The amount of 
magnetite in the rock can be inferred from the magnetic susceptibility, using for example the relationship presented by Zablocki (1974). For our samples, there is a poor correlation between magnetic susceptibility and resistivity (Fig. 12), suggesting that magnetite plays a minor role in controlling sample resistivities compared to the connectivity of porous networks. This observation is consistent with previous work that suggested the rarity (or possible absence) of serpentinite with well-connected magnetite networks (Evans et al., 2010).

\subsection{Stress dependence of the elastic constants}

The $\mathrm{P}$ - to $\mathrm{S}$-wave velocity ratio $\left(\mathrm{V}_{\mathrm{p}} / \mathrm{V}_{\mathrm{s}}\right)$, or equivalently Poisson's ratio (Fig. 13) provides further information about the internal structure of the rock. S1 and S5 have $V_{p} / V_{s}$ ratios above 2.2 during the initial loading stages, which may be related to the cumulative effect of crack anisotropy and high pore pressure (Wang et al., 2012); in $\mathrm{S} 1$, it is likely related to a preferential talc orientation, though. According to Mainprice et al. (2008), $V_{p} / V_{s}>1.7$ would be indicating talc anisotropy, with a maximum in the basal plane of the mineral $\left(V_{p} / V_{s}>2.5\right)$. Since our samples were cored perpendicular to the original cores, vertically drilled into the seafloor, we infer that the layering of talc overprinting the original serpentinization might be preferentially sub-vertical at the sample scale. Furthermore, low elastic wave velocities and high $V_{p} / V_{s}$ such as those of S2 and S5 (and to a lesser extent to S4) have been associated elsewhere with foliated serpentinites with foliation sub-perpendicular to the direction of elastic wave propagation (Bezacier et al., 2010). Also, the permeability we have measured along this direction (i.e., parallel to foliation) reflects the horizontal component of the permeability in each case, which can be up to 10 times lower than the vertical component (Manning and Ingebritsen, 1999). 
S2 has increasing $V_{p} / V_{s}$ with increasing stress, which is symptomatic of increased cracking, as also inferred from the hysteresis in resistivity and permeability, and by visually observed permanent damage to the sample after pressure was released. This stress-induced deformation complicates the elasticcompositional interpretations for S2.

Elastic moduli are important parameters to evaluate the stiffness of the rock. They depend on the composition and the texture of the sample. Christensen (1966) measured $\mathrm{P}$ - and S-wave velocities for a wide range of ultramafic rocks up to $1 \mathrm{GPa}$ of differential stress, and found that Young's modulus (E), and bulk and shear moduli ( $K$ and $G$ ), decrease with the degree of serpentinization, whereas Poisson's ratio ( $v$ ) increases. Miller and Christensen (1997) pointed out that the presence of serpentinite can also be inferred from the Poisson's ratio, which is higher than that of most other silicate rocks. From the elastic constants of our samples (Fig. 13), we can infer that the degree of serpentinization varies as $\mathrm{S} 1<\mathrm{S} 4<\mathrm{S} 5<\mathrm{S} 2$, which agrees with our preliminary serpentinized fraction estimates (Table 1) and is not far from those derived from petrographic analysis (Table 2).

Based on least squares analysis carried out by Christensen (2004) using available data on ultramafic rock velocities and densities, the Poission's ratio at the maximum differential stress of our samples indicates that the degree of serpentinization is above $80 \%$ in all the cases (S1 and S4 $~ 80 \%$; S2 and S5 90 $95 \%)$. As previously discussed, the presence of talc in S1 leads to misleading compositional interpretations, and the previous relation cannot be applied. Aside from that, this observation is consistent with the results of our petrographic analysis, even though Christensen's (2004) regression is representative of much higher pressures and temperature (200 MPa and $\left.200{ }^{\circ} \mathrm{C}\right)$. 


\section{Conclusions}

We have measured the elastic properties, electrical resistivity and permeability on four serpentinized samples from the southern wall of the Atlantis Massif, MidAtlantic Ridge, collected during IODP Expedition 357. These parameters show useful correlations that ultimately might be used to distinguish between chemical and mechanical alteration.

Our results show lower permeability $\left(10^{-14}\right.$ to $\left.10^{-20} \mathrm{~m}^{2}\right)$ than values previously reported for serpentinized peridotites. The high pressure dependence of permeability and similarly for elastic parameters $\left(V_{p}, V_{s}\right.$ and $\left.Q_{p}\right)$ and electrical resistivity, together with some anomalously high porosities, suggest some degree of hydromechanical alteration. Though, the good correlation found between permeability and the elastic and electrical properties may contribute towards improving the understanding of fluid pathways in hydrothermal systems.

The electrical resistivity shows large contrasts between hydromechanically altered serpentinized (below $20 \Omega \mathrm{m}$ ) and massive serpentinized (above $~ 50 \Omega \mathrm{m}$ ) ultramafic rocks. This contrast, together with the elastic constants of the rock provides constraints on the degree of serpentinization, as corroborated by petrographic analysis. However, post-serpentinization metasomatic alteration has the potential to mask the previous estimations and may lead to misleading interpretations.

\section{Acknowledgments}

We acknowledge support from the United Kingdom (UK) Natural Environment Research Council and IODP Phase 2 grant NE/N012402/1 and IODP/ECORD for 
funding the expedition and providing samples. Also, we acknowledge ESO operators as well as the RD2 drill team and the co-chief scientists, G. Früh-Green and B.

Orcutt, for enabling the samples to be collected and thank the co-chiefs for reviewing the manuscript. The experimental apparatus was jointly funded by NERC and the UK Engineering and Physical Sciences Research Council (EPSRC) under a separate programme (EP/K035878/1). Minshull was supported by a Wolfson Research Merit award. Rouméjon was supported by Swiss National Science Foundation Grant $200021-163187$. 


\section{References}

Amalokwu, K., Best, A.I., Sothcott, J., Chapman, M., Minshull, T. \& Li, X.-Y., 2014. Water saturation effects on elastic wave attenuation in porous rocks with aligned fractures, Geophysical Journal International, 197, 943-947.

Andy, A. \& William, R.B.L., 2006. Uses and abuses of EIDORS: an extensible software base for EIT, Physiological Measurement, 27, S25.

Asef, M.R. \& Najibi, A.R., 2013. The effect of confining pressure on elastic wave velocities and dynamic to static Young's modulus ratio, Geophysics, 78, D135-D142.

Bayrakci, G., Minshull, T.A., Sawyer, D.S., Reston, T.J., Klaeschen, D., Papenberg, C., Ranero, C., Bull, J.M., Davy, R.G., Shillington, D.J., Perez-Gussinye, M. \& Morgan, J.K., 2016. Fault-controlled hydration of the upper mantle during continental rifting, Nature Geosci, 9, 384-388.

Best, A.I., 1992. The prediction of the reservoir properties of sedimentary rocks from seismic measurements, Ph.D. thesis, University of Reading.

Best, A.I., Sothcott, J. \& McCann, C., 2007. A laboratory study of seismic velocity and attenuation anisotropy in near-surface sedimentary rocks, Geophysical Prospecting, 55, 609-625.

Bezacier, L., Reynard, B., Bass, J.D., Sanchez-Valle, C. \& Van de Moortèle, B., 2010. Elasticity of antigorite, seismic detection of serpentinites, and anisotropy in subduction zones, Earth and Planetary Science Letters, 289, 198-208. 
Blackman, D.K., Cann, J.R., Janssen, B. \& Smith, D.K., 1998. Origin of extensional core complexes: Evidence from the Mid-Atlantic Ridge at Atlantis Fracture Zone, Journal of Geophysical Research: Solid Earth, 103, 21315-21333.

Blackman, D.K., Ildefonse, B., John, B.E., Ohara, Y., Miller, D.J., Abe, N., Abratis, M., Andal, E.S., Andreani, M., Awaji, S., Beard, J.S., Brunelli, D., Charney, A.B., Christie, D.M., Collins, J., Delacour, A.G., Delius, H., Drouin, M., Einaudi, F., Escartín, J., Frost, B.R., Früh-Green, G., Fryer, P.B., Gee, J.S., Godard, M., Grimes, C.B., Halfpenny, A., Hansen, H.E., Harris, A.C., Tamura, A., Hayman, N.W., Hellebrand, E., Hirose, T., Hirth, J.G., Ishimaru, S., Johnson, K.T.M., Karner, G.D., Linek, M., MacLeod, C.J., Maeda, J., Mason, O.U., McCaig, A.M., Michibayashi, K., Morris, A., Nakagawa, T., Nozaka, T., Rosner, M., Searle, R.C., Suhr, G., Tominaga, M., von der Handt, A., Yamasaki, T. \& Zhao, X., 2011. Drilling constraints on lithospheric accretion and evolution at Atlantis Massif, Mid-Atlantic Ridge $30^{\circ} \mathrm{N}$, Journal of Geophysical Research: Solid Earth, 116, B07103.

Boillot, G., Winterer, E.L., Meyer, A.W., Applegate, J., Baltuck, M., Bergen, J.A., Comas, M.C., Davies, T.A., Dunham, K., Evans, C.A., Girardeau, J., Goldberg, D., Haggerty, J.A., Jansa, L.F., Johnson, J.A., Kasahara, J., Loreau, J.-P., Luna, E., Moullade, M., Ogg, J.G., Sarti, M., Thurow, J. \& Williamson, M.A., 1987. Introduction, objectives, and principal results; Ocean Drilling Program Leg 103, West Galicia margin, CODEN: IDSDA6, 103, 3-17.

Boschi, C., Früh-Green, G.L., Delacour, A., Karson, J.A. \& Kelley, D.S., 2006. Mass transfer and fluid flow during detachment faulting and development of an oceanic core complex, Atlantis Massif (MAR $30^{\circ} \mathrm{N}$ ), Geochemistry, Geophysics, Geosystems, 7, Q01004. 
Brace, W.F., Walsh, J.B. \& Frangos, W.T., 1968. Permeability of Granite under High Pressure, Journal of Geophysical Research, 73, 2225-2236.

Brereton, N.R., 1992. Physical property relationships from Sites 765 and 766, pp. 453-468, ed. Gradstein, F. M., Ludden, J.N., et al., Proc. ODP, Sci. Results, 123: College Station, TX (Ocean Drilling Program).

Cannat, M., Karson, J.A., Miller, D.J., Agar, S.M., Barling, J., Casey, J.F., Ceuleneer, G., Dilek, Y., Fletcher, J., Fujibayashi, N., Gaggero, L., Gee, J.S., Hurst, S.D., Kelley, D.S., Kempton, P.D., Lawrence, R.M., Marchig, V., Mutter, C., Niida, K., Rodway, K., Ross, D.K., Stephens, C., Werner, C.-D. \& Whitechurch, H., 1995. Introduction, Proceedings of the Ocean Drilling Program, initial reports, Mid-Atlantic Ridge; covering Leg 153 of the cruises of the drilling vessel JOIDES Resolution, St. John's Harbor, Newfoundland, to Bridgetown, Barbados, sites 920-924, 22 November 1993-20 January 1994, 153, 5-13.

Carlson, R.L. \& Miller, D.J., 2003. Mantle wedge water contents estimated from seismic velocities in partially serpentinized peridotites, Geophysical Research Letters, 30, 1250.

Carlson, R.L. \& Miller, J.D., 2004. Influence of pressure and mineralogy on seismic velocities in oceanic gabbros: Implications for the composition and state of the lower oceanic crust, Journal of Geophysical Research: Solid Earth, 109, B09205.

Christensen, N.I., 1966. Elasticity of ultrabasic rocks, Journal of Geophysical Research, 71, 5921-5931.

Christensen, N.I., 2004. Serpentinites, Peridotites, and Seismology, International Geology Review, 46, 795-816. 
Denny, A.R., Kelley, D.S. \& Früh-Green, G.L., 2015. Geologic evolution of the Lost City Hydrothermal Field, Geochemistry, Geophysics, Geosystems, 17, 375394.

Escartín, J. \& Cannat, M., 1999. Ultramafic exposures and the gravity signature of the lithosphere near the Fifteen-Twenty Fracture Zone (Mid-Atlantic Ridge, $\left.14^{\circ}-16.5^{\circ} \mathrm{N}\right)$, Earth and Planetary Science Letters, 171, 411-424.

Escartín, J., Hirth, G. \& Evans, B., 2001. Strength of slightly serpentinized peridotites: Implications for the tectonics of oceanic lithosphere, Geology, 29, 1023-1026.

Evans, R.L., Escartín, J. \& Cannat, M., 2010. A short electromagnetic profile across the Kane Oceanic Core Complex, Geophysical Research Letters, 37, n/a-n/a.

Falcon-Suarez, I., North, L., Amalokwu, K. \& Best, A., 2016. Integrated geophysical and hydromechanical assessment for $\mathrm{CO} 2$ storage: shallow low permeable reservoir sandstones, Geophysical Prospecting, 64, 828-847.

Falcon-Suarez , I., Rodriguez-Cedrun, B., Canal-Vila, J. \& Delgado-Martin, J., 2014. Application of transient methods to the assessment of permeability of well cements. in Rock Engineering and Rock Mechanics: Structures in and on Rock Masses, pp. 1295-1299CRC Press.

Fisher, A.T., 1998. Permeability within basaltic oceanic crust, Reviews of Geophysics, 36, 143-182.

Früh-Green, G.L., Kelley, D.S., Bernasconi, S.M., Karson, J.A., Ludwig, K.A., Butterfield, D.A., Boschi, C. \& Proskurowski, G., 2003. 30,000 Years of Hydrothermal Activity at the Lost City Vent Field, Science, 301, 495-498. 
Früh-Green, G.L., Orcutt, B.N., Green, S., Cotterill, C., and the Expedition 357 Scientists, 2016. Expedition 357 Preliminary Report: Atlantis Massif Serpentinization and Life. International Ocean Discovery Program.

Früh-Green, G.L., Orcutt, B.N., Green, S.L., Cotterill, C., and the Expedition 357 Scientists, 2017. Atlantis Massif Serpentinization and Life. Proceedings of the International Ocean Discovery Program, 357: College Station, TX (International Ocean Discovery Program).

Fryer, P., Pearce, J.A., Stokking, L.B., Ali, J.R., Arculus, R., Ballotti, D.L., Burke, M.M., Ciampo, G., Haggerty, J.A., Haston, R.B., Heling, D., Hobart, M.A., Ishii, T., Johnson, L.E., Lagabrielle, Y., McCoy, F.W., Maekawa, H., Marlow, M.S., Milner, G., Mottl, M.J., Murton, B.J., Phipps, S.P., Rigsby, C.A., Saboda, K.L., Stabell, B., van der Laan, S. \& Xu, Y., 1990. Introduction, Proceedings of the Ocean Drilling Program, initial reports; Bonin/Mariana region, covering Leg 125 of the cruises of the drilling vessel JOIDES Resolution, Apra Harbor, Guam, to Tokyo, Japan, sites 778-786, 15 February 1989-17 April 1989, 125, 5-14.

Grimes, C.B., John, B.E., Cheadle, M.J. \& Wooden, J.L., 2008. Protracted construction of gabbroic crust at a slow spreading ridge: Constraints from 206Pb/238U zircon ages from Atlantis Massif and IODP Hole U1309D (30N, MAR), Geochemistry, Geophysics, Geosystems, 9, n/a-n/a.

Guillot, S., Schwartz, S., Reynard, B., Agard, P. \& Prigent, C., 2015. Tectonic significance of serpentinites, Tectonophysics, 646, 1-19.

Guo, X., Yoshino, T. \& Katayama, I., 2011. Electrical conductivity anisotropy of deformed talc rocks and serpentinites at $3 \mathrm{GPa}$, Physics of the Earth and Planetary Interiors, 188, 69-81. 
Hirth, G. \& Guillot, S., 2013. Rheology and Tectonic Significance of Serpentinite, Elements, 9, 107-113.

Horen, H., Zamora, M. \& Dubuisson, G., 1996. Seismic waves velocities and anisotropy in serpentinized peridotites from xigaze ophiolite: Abundance of serpentine in slow spreading ridge, Geophysical Research Letters, 23, 9-12.

Iturrino, G.J., Christensen, N.I., Kirby, S. \& Salisbury, M.H., 1991. Seismic velocities and elastic properties of gabbroic rocks from ODP Hole 118-735B. in Supplement to: Iturrino, GJ et al. (1991): Seismic velocities and elastic properties of oceanic gabbroic rocks from Hole 735B. In: Von Herzen, RP; Robinson, PT; et al. (eds.), Proceedings of the Ocean Drilling Program, Scientific Results, College Station, TX (Ocean Drilling Program), 118, 227244, doi:10.2973/odp.proc.sr.118.151.1991PANGAEA.

Karson, J.A., Früh-Green, G.L., Kelley, D.S., Williams, E.A., Yoerger, D.R. \& Jakuba, M., 2006. Detachment shear zone of the Atlantis Massif core complex, MidAtlantic Ridge, $30^{\circ} \mathrm{N}$, Geochemistry, Geophysics, Geosystems, 7, n/a-n/a. Katayama, I., Terada, T., Okazaki, K. \& Tanikawa, W., 2012. Episodic tremor and slow slip potentially linked to permeability contrasts at the Moho, Nature Geosci, 5, 731-734.

Kawano, S., Katayama, I. \& Okazaki, K., 2011. Permeability anisotropy of serpentinite and fluid pathways in a subduction zone, Geology, 39, 939-942.

Kelley, D.S., Karson, J.A., Blackman, D.K., Fruh-Green, G.L., Butterfield, D.A., Lilley, M.D., Olson, E.J., Schrenk, M.O., Roe, K.K., Lebon, G.T., Rivizzigno, P. \& the, A.T.S.P., 2001. An off-axis hydrothermal vent field near the Mid-Atlantic Ridge at 30[deg] N, Nature, 412, 145-149. 
Kelley, D.S., Karson, J.A., Früh-Green, G.L., Yoerger, D.R., Shank, T.M., Butterfield, D.A., Hayes, J.M., Schrenk, M.O., Olson, E.J., Proskurowski, G., Jakuba, M., Bradley, A., Larson, B., Ludwig, K., Glickson, D., Buckman, K., Bradley, A.S., Brazelton, W.J., Roe, K., Elend, M.J., Delacour, A., Bernasconi, S.M., Lilley, M.D., Baross, J.A., Summons, R.E. \& Sylva, S.P., 2005. A SerpentiniteHosted Ecosystem: The Lost City Hydrothermal Field, Science, 307, 14281434.

Kranz, R.L., Saltzman, J.S. \& Blacic, J.D., 1990. Hydraulic diffusivity measurements on laboratory rock samples using an oscillating pore pressure method, International Journal of Rock Mechanics and Mining Sciences \& Geomechanics Abstracts, 27, 345-352.

Macdonald, A.H. \& Fyfe, W.S., 1985. Oceanic LithosphereRate of serpentinization in seafloor environments, Tectonophysics, 116, 123-135.

Mainprice, D., Le Page, Y., Rodgers, J. \& Jouanna, P., 2008. Ab initio elastic properties of talc from 0 to $12 \mathrm{GPa}$ : Interpretation of seismic velocities at mantle pressures and prediction of auxetic behaviour at low pressure, Earth and Planetary Science Letters, 274, 327-338.

Manning, C.E. \& Ingebritsen, S.E., 1999. Permeability of the continental crust: Implications of geothermal data and metamorphic systems, Reviews of Geophysics, 37, 127-150.

McCann, C. \& Sothcott, J., 1992. Laboratory measurements of the seismic properties of sedimentary rocks, Geological Society, London, Special Publications, 65, 285-297. 
Metwally, Y.M. \& Sondergeld, C.H., 2011. Measuring low permeabilities of gassands and shales using a pressure transmission technique, International Journal of Rock Mechanics and Mining Sciences, 48, 1135-1144.

Miller, D.J. \& Christensen, N.I., 1997. Seismic velocities of lower crustal and upper mantle rocks from the slow-spreading Mid-Atlantic Ridge, south of the Kane Transform Zone (MARK). Karson, J.A., Cannat, M., Miller, D.J., and Elthon, D. (Eds.), Proc. ODP, Sci. Results, 153: College Station, TX (Ocean Drilling Program), 437-454.

Minshull, T.A., 2009. Geophysical characterisation of the ocean-continent transition at magma-poor rifted margins, Comptes Rendus Geoscience, 341, 382-393.

Moore, D.E., Lockner, D.A., Summers, R., Shengli, M. \& Byerlee, J.D., 1996. Strength of chrysotile-serpentinite gouge under hydrothermal conditions: Can it explain a weak San Andreas fault?, Geology, 24, 1041-1044.

Müller, T.M., Gurevich, B. \& Lebedev, M., 2010. Seismic wave attenuation and dispersion resulting from wave-induced flow in porous rocks - A review, Geophysics, 75, 75A147-175A164.

North, L., Best, A.I., Sothcott, J. \& MacGregor, L., 2013. Laboratory determination of the full electrical resistivity tensor of heterogeneous carbonate rocks at elevated pressures, Geophysical Prospecting, 61, 458-470.

Plümper, O., Røyne, A., Magrasó, A. \& Jamtveit, B., 2012. The interface-scale mechanism of reaction-induced fracturing during serpentinization, Geology.

Popp, T. \& Kern, H., 1993. Thermal dehydration reactions characterised by combined measurements of electrical conductivity and elastic wave velocities, Earth and planetary science letters, 120, 43-57. 
Reynard, B., Mibe, K. \& Van de Moortèle, B., 2011. Electrical conductivity of the serpentinised mantle and fluid flow in subduction zones, Earth and Planetary Science Letters, 307, 387-394.

Schroeder, T. \& John, B.E., 2004. Strain localization on an oceanic detachment fault system, Atlantis Massif, $30^{\circ} \mathrm{N}$, Mid-Atlantic Ridge, Geochemistry, Geophysics, Geosystems, 5, n/a-n/a.

Stesky, R.M. \& Brace, W.F., 1973. Electrical conductivity of serpentinized rocks to 6 kilobars, Journal of Geophysical Research, 78, 7614-7621.

Whitmarsh, R.B., Beslier, M.-O., Wallace, P.J., Abe, N., Basile, C., Beard, J.S., Froitzheim, N., Gardien, V., Hebert, R., Hopkinson, L.J., Kudless, K.E., Louvel, V., Manatschal, G., Newton, A.C., Rubenach, M.J., Skelton, A.D.L., Smith, S.E., Takayama, H., Tompkins, M.J., Turrin, B.D., Urquhart, E., Wallrabe-Adams, H.-J., Wilkens, R.H., Wilson, R.C.L., Wise, S.W., Jr. \& Zhao, X., 1998. Leg 173 introduction, Proceedings of the Ocean Drilling Program, Initial reports, return to Iberia, covering Leg 173 of the cruises of the drilling vessel JOIDES Resolution, Lisbon, Portugal, to Halifax, Nova Scotia, sites 1065-1070, 15 April-15 June 1997, 173, 7-23.

Xie, H.-S., Zhou, W.-G., Zhu, M.-X., Liu, Y.-G., Zhao, Z.-D. \& Guo, J., 2002. Elastic and electrical properties of serpentinite dehydration at high temperature and high pressure, Journal of Physics: Condensed Matter, 14, 11359.

Zablocki, C.J., 1974. Magnetite assays from magnetic susceptibility measurements in taconite production blast holes, Northern Minnesota, Geophysics, 39, 174189. 


\section{Tables}

Table 1. Sample properties

\begin{tabular}{ccccccccc}
\hline Sample & Location & Core & Interval & Depth & $\phi$ & $\rho_{b}$ & $\rho_{\mathrm{s}}$ & $\begin{array}{c}\text { Serpentinized } \\
\text { fraction }\end{array}$ \\
& (Hole) & (section) & $(\mathrm{cm})$ & $(\mathrm{mbsf})$ & & $\left(\mathrm{kg} \mathrm{m}^{-3}\right)$ & $\left(\mathrm{kg} \mathrm{m}^{-3}\right)$ & 0.59 \\
S1 & M0068B & $1 \mathrm{R}-1$ & $12-18$ & 0.12 & 0.026 & 2786 & 2833 & 0.98 \\
S2 & M0076B & $8 \mathrm{R}-1$ & $120-128$ & 12.356 & 0.101 & 2374 & 2534 & 0.88 \\
S4 & M0076B & 7R-1 & $77-83$ & 10.004 & 0.076 & 2483 & 2606 & 0.86 \\
\hline
\end{tabular}

* Based on empirical relationship presented by Miller and Christensen (1997)

Table 2. Primary and secondary mineralogy estimated from thin section analysis

\begin{tabular}{|c|c|c|c|c|c|c|c|c|c|}
\hline \multirow[t]{2}{*}{ Sample } & \multirow[t]{2}{*}{ Rock description } & \multicolumn{4}{|c|}{$\begin{array}{l}\text { * Primary mineralogy } \\
\text { (present / original \%) }\end{array}$} & \multicolumn{4}{|c|}{ * Secondary mineralogy (\%) } \\
\hline & & Ol & Opx & Clpx & Sp & Serp (+Mag) & $\mathrm{Chl}+\mathrm{Tr}+\mathrm{Ac}$ & Tc & $\mathrm{C}$ \\
\hline S1 & $\begin{array}{l}\text { Metasomatised } \\
\text { serpentinized } \\
\text { harzburgite }\end{array}$ & $0 / 80$ & $0 / 20$ & & $<1$ & 0 & 10 & 90 & \\
\hline $\mathrm{S} 2$ & $\begin{array}{l}\text { serpentinized } \\
\text { harzburgite }\end{array}$ & $0 / 90$ & $0 / 5$ & $0 / 5$ & $<1$ & 90 & & & 10 \\
\hline S4 & $\begin{array}{l}\text { Porphyroclastic } \\
\text { serpentinite }\end{array}$ & $0 / 80$ & $0 / 10$ & $0 / 4$ & 1 & 85 & 14 & & \\
\hline S5 & $\begin{array}{l}\text { Serpentinized } \\
\text { dunite }\end{array}$ & $0 / 95$ & & & 5 & 94 & & & \\
\hline
\end{tabular}

* Ol, olivine; Opx, orthopyroxene; Clpx, clinopiroxene; Sp, spinele; Serp, serpentinite; Mag, magnetite; Chl, chloride; Tr, tremolite; Tc, talc; C, carbonates. 


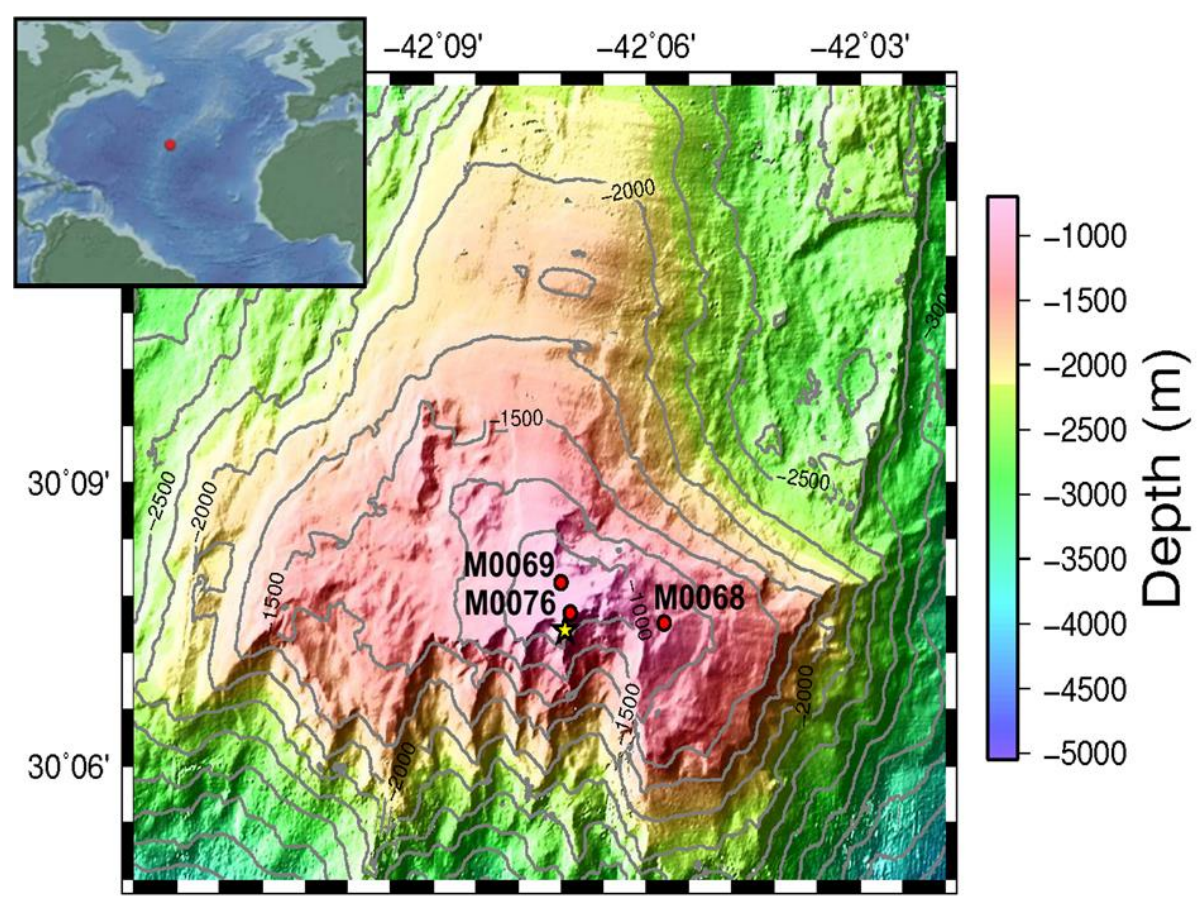

Figure 1. Bathymetry of the Atlantic Massif oceanic core complex, Mid-Atlantic Ridge (Früh-Green et al., 2016), with the position of Exp. 357 drill sites (red circles) of samples used in this study. Yellow star indicates the position of the Lost City Hydrothermal Field (LCHF). 


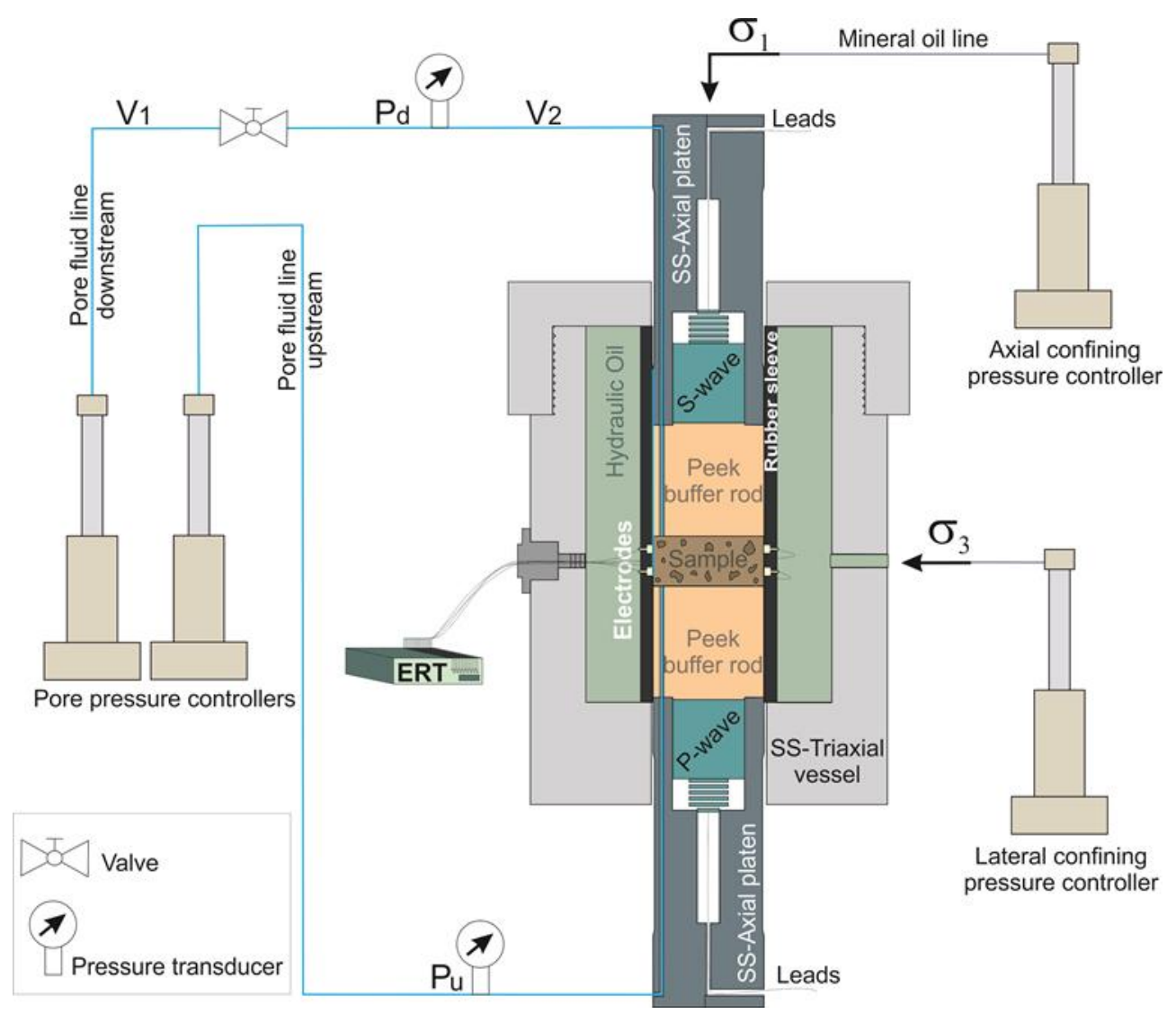

Figure 2. Experimental rig showing ultrasonic pulse-echo ( $P$ - \& S-wave) and electrical resistivity tomography (ERT) systems with pore fluid and confining pressure control systems.

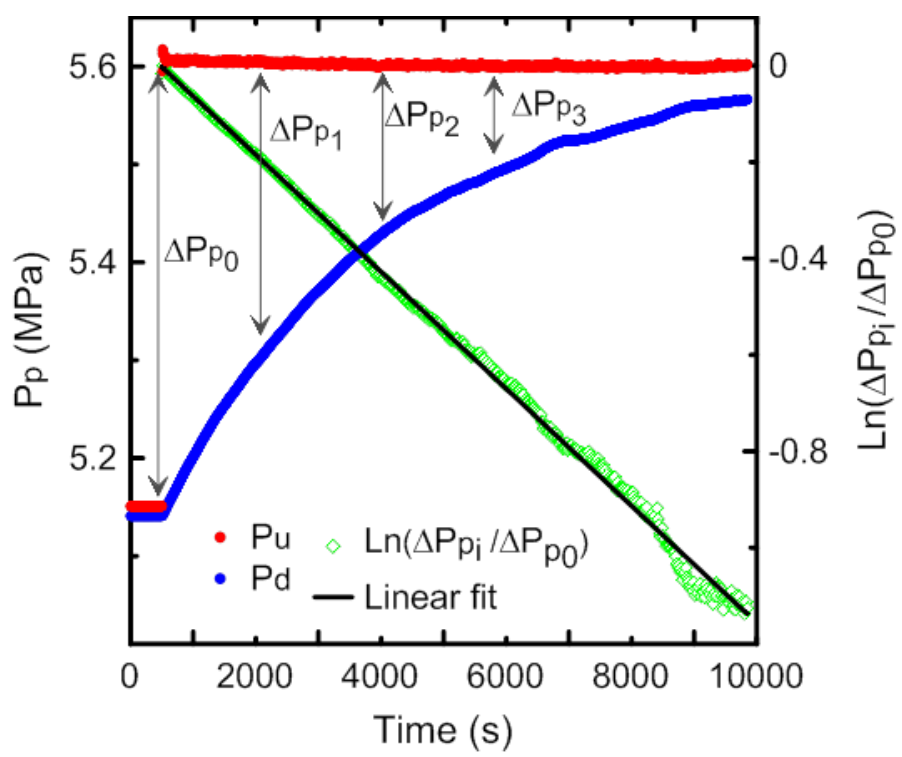

Figure 3. Example of the permeability test based on the pore pressure transmission 
technique (Metwally and Sondergeld, 2011), where $P_{p}$ is pore pressure, while $P_{u}$ and $P_{d}$ are pore pressure up- and downstream of the rock sample, respectively. This example corresponds to the permeability test of $\mathrm{S} 1$ at the maximum differential stress (45 MPa).

S1

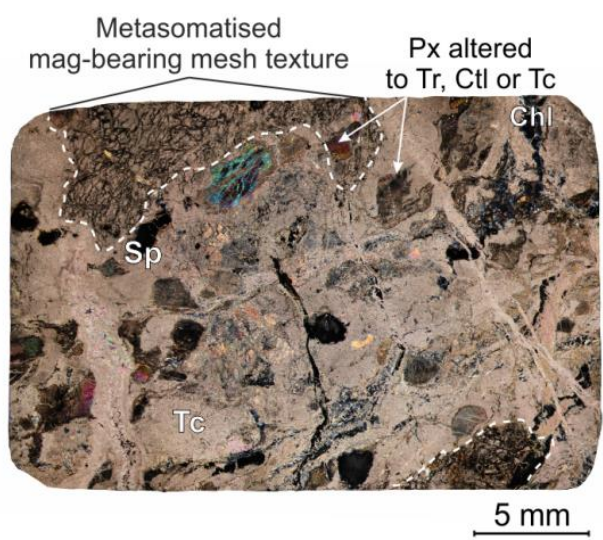

S4

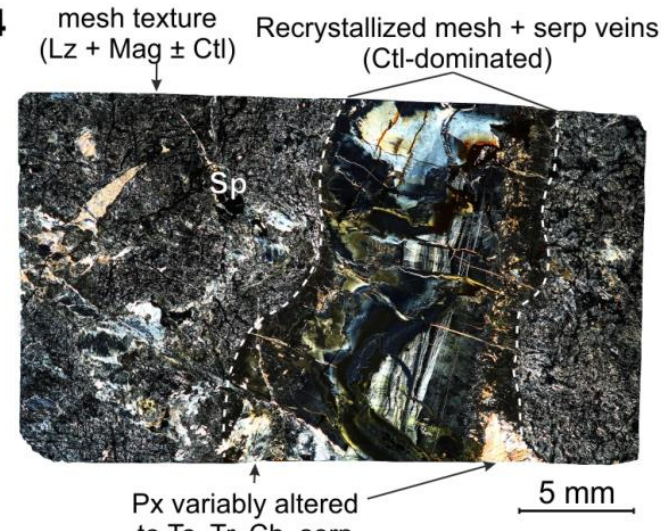

S2

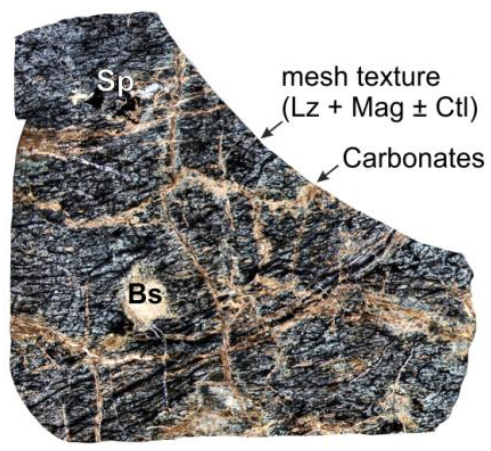

$5 \mathrm{~mm}$

\section{S5}

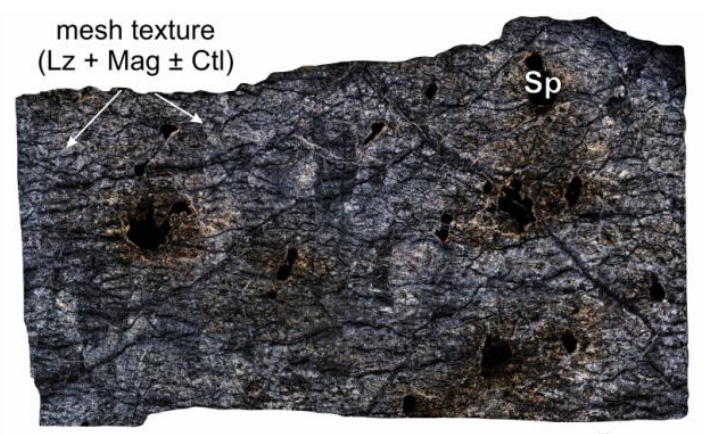

$5 \mathrm{~mm}$

Figure 4. Textures and mineralogical assemblages in thin sections (oriented parallel to the horizontal plane) on the four serpentinized peridotites selected for this study. Photos taken under cross-polarized light. OI, olivine; Opx, orthopyroxene; Clpx, clinopiroxene; Sp, spinele; Serp, serpentinite; Mag, magnetite; Chl, chloride; Tr, tremolite; Tc, talc; C, carbonates. 
(a)

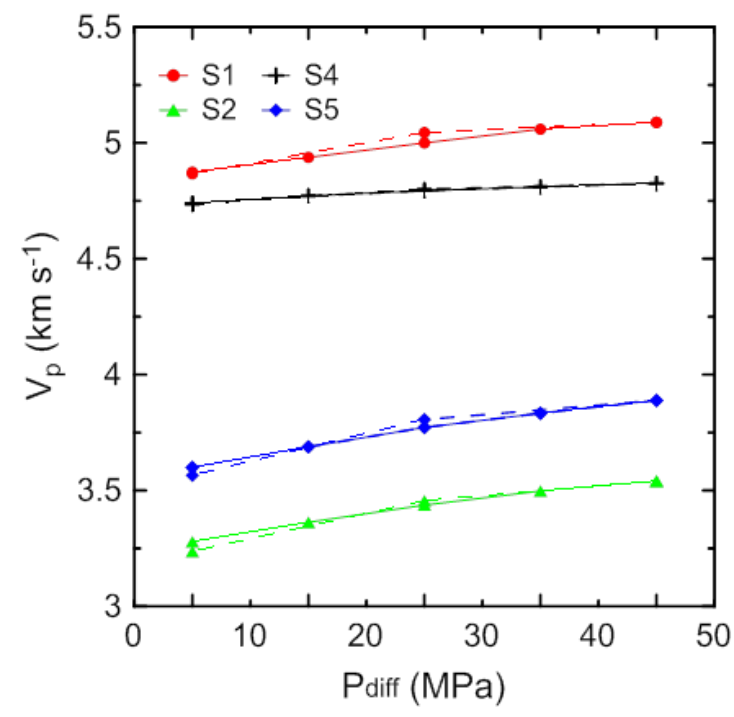

(b)

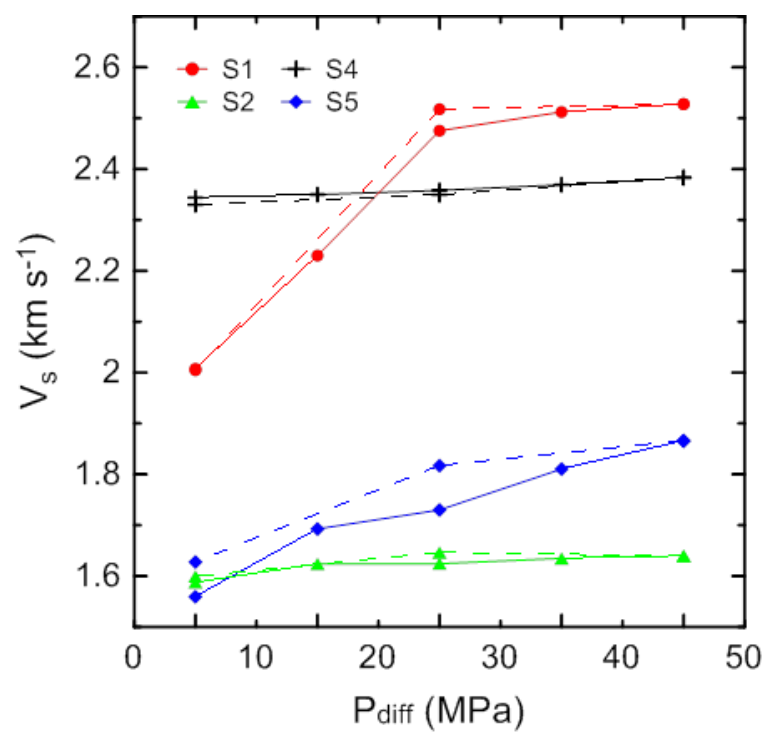

Figure 5. (a) and (b), variation with differential stress $\left(P_{\text {diff }}\right)$ of ultrasonic $P$ - and S-wave velocities $\left(V_{p}, V_{s}\right)$ for loading (solid line) and unloading (dashed line) stress conditions.

(a)

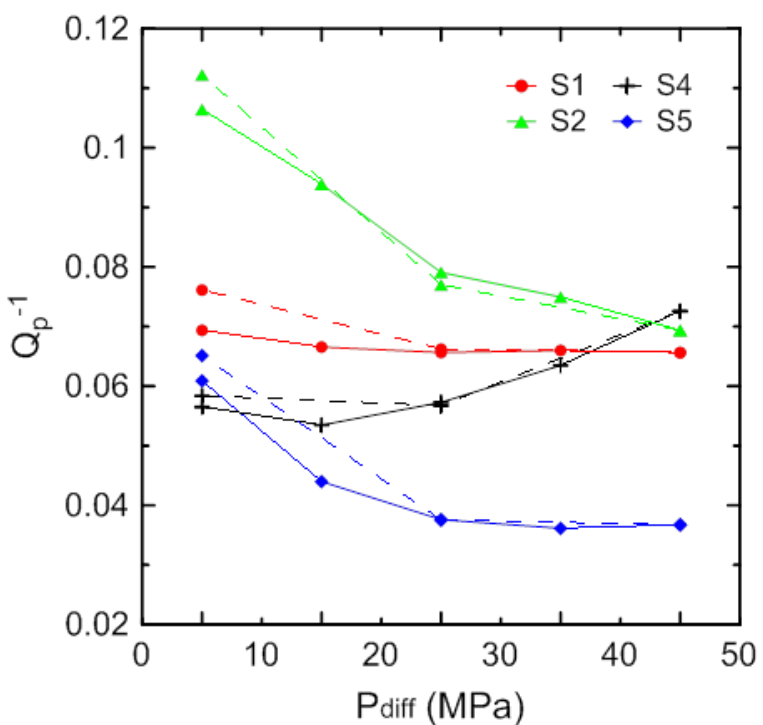

(b)

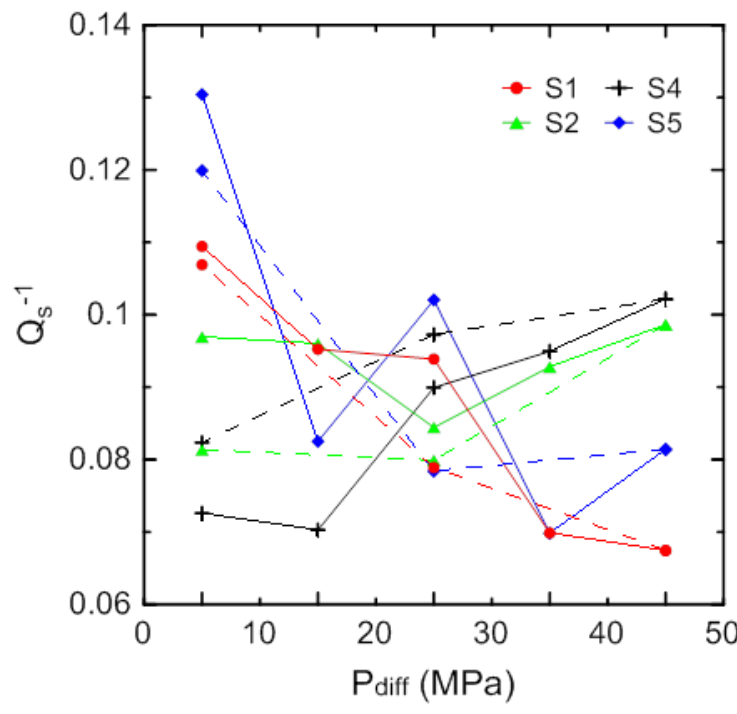

Figure 6. (a) and (b), differential stress-dependence $\left(\mathrm{P}_{\text {diff }}\right)$ of ultrasonic $\mathrm{P}$ - and S-wave 
attenuations $\left(Q_{p}^{-1}, Q_{s}^{-1}\right)$ for loading (solid line) and unloading (dashed line) stress conditions.

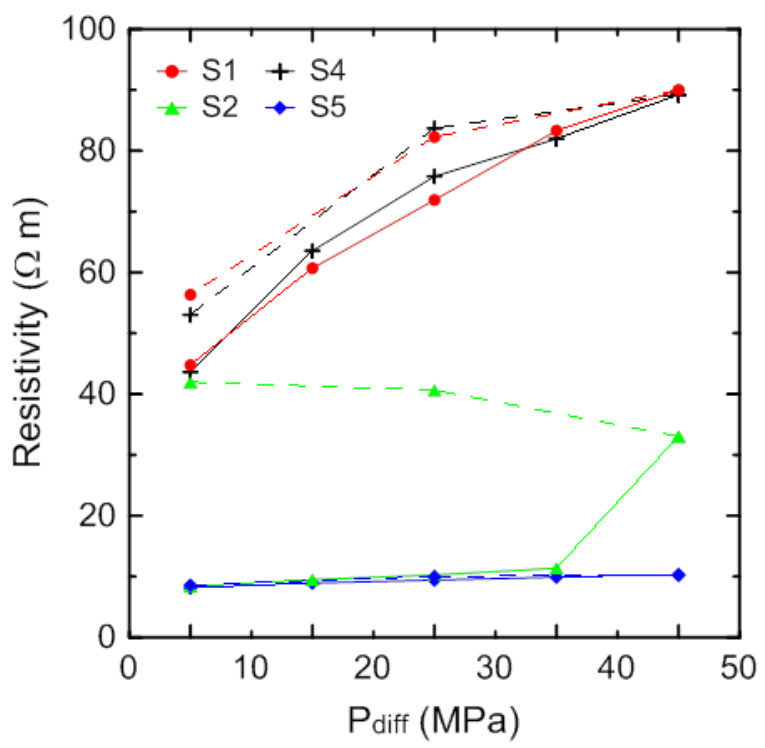

Figure 7. Electrical resistivity (resistivity) versus differential stress $\left(P_{\text {diff }}\right)$ for loading (solid line) and unloading (dashed line) stress conditions. 

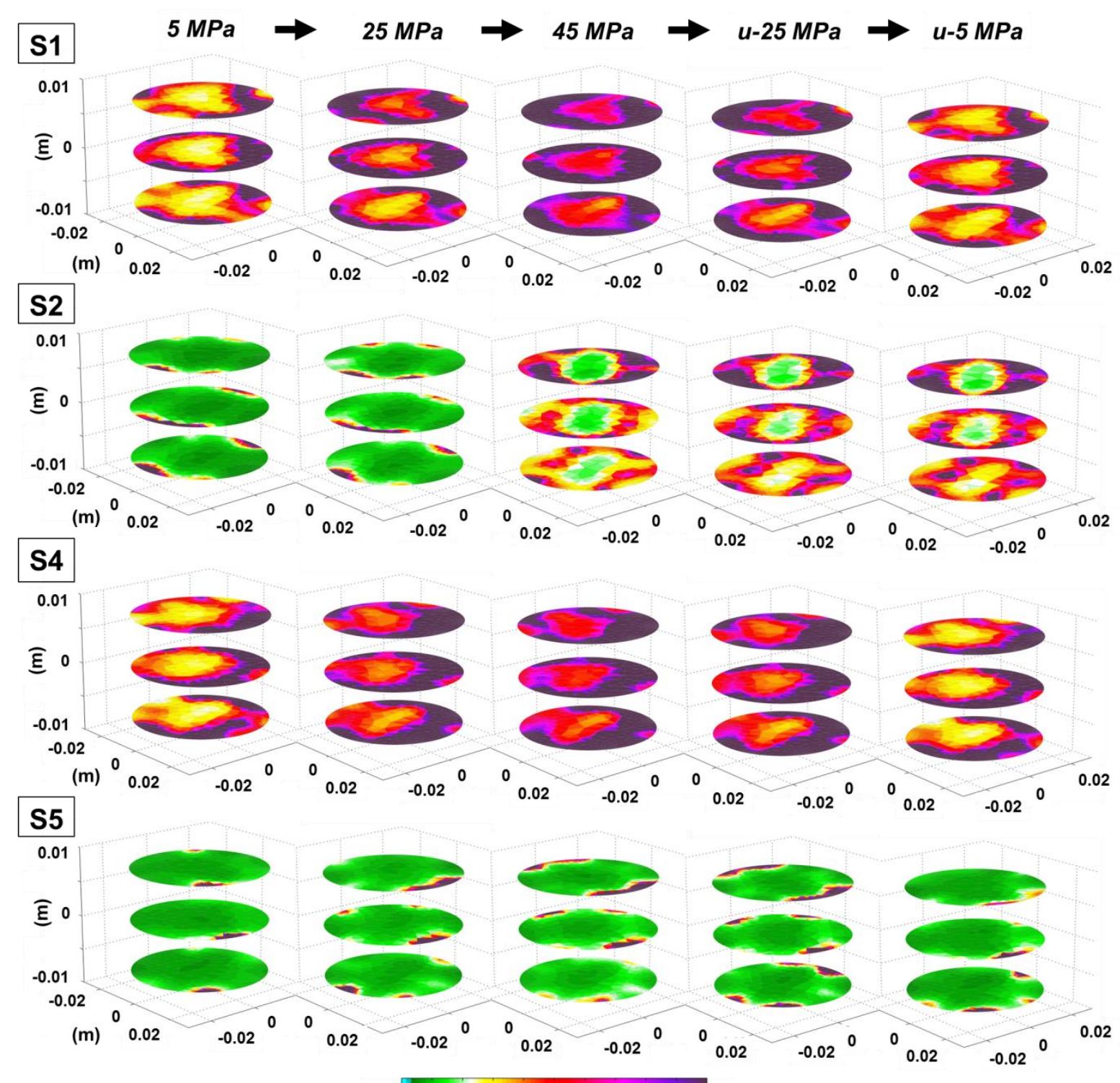

$0 \quad 102030405060708090100$

Resistivity $(\Omega \mathrm{m})$

Figure 8. 3D electrical resistivity tomography slices at three loading $(5,25$ and $45 \mathrm{MPa})$ and the two unloading ( 25 and $5 \mathrm{MPa}$, denoted with prefix ' $u$ ') differential stress for the four samples (S1, S2, S4 and S5). Slices are cross-sections at the middle of the sample and $0.75 \mathrm{~cm}$ above and below, respectively. 
(a)

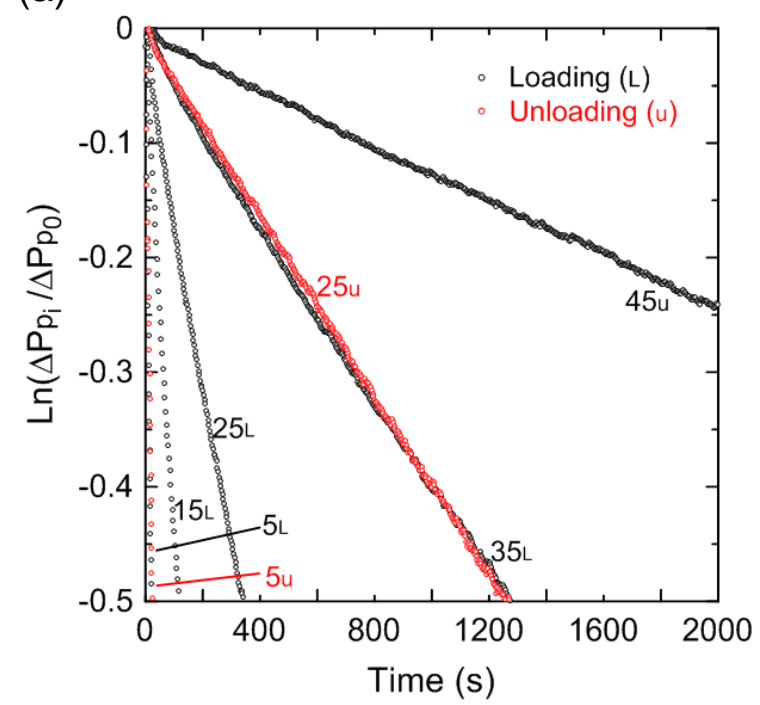

(c)

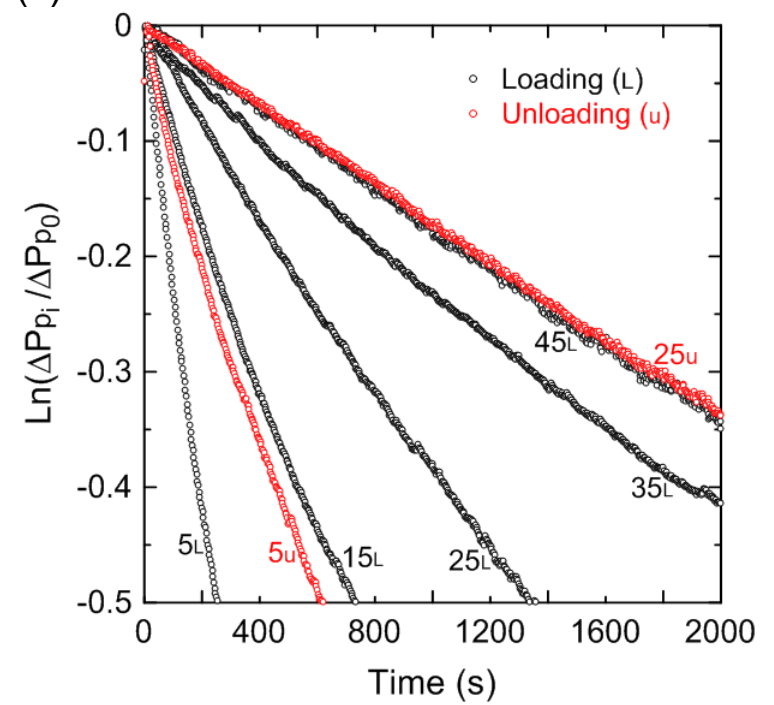

(b)

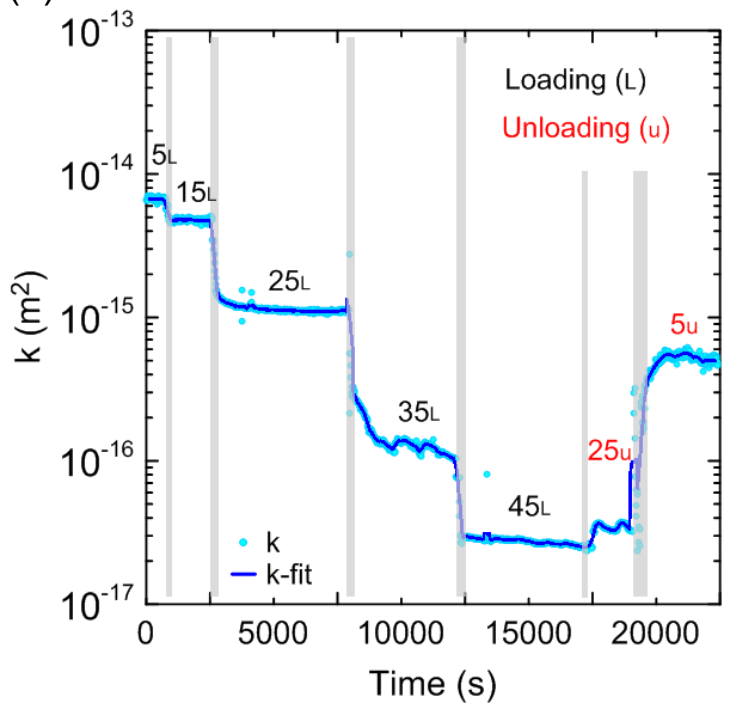

(d)

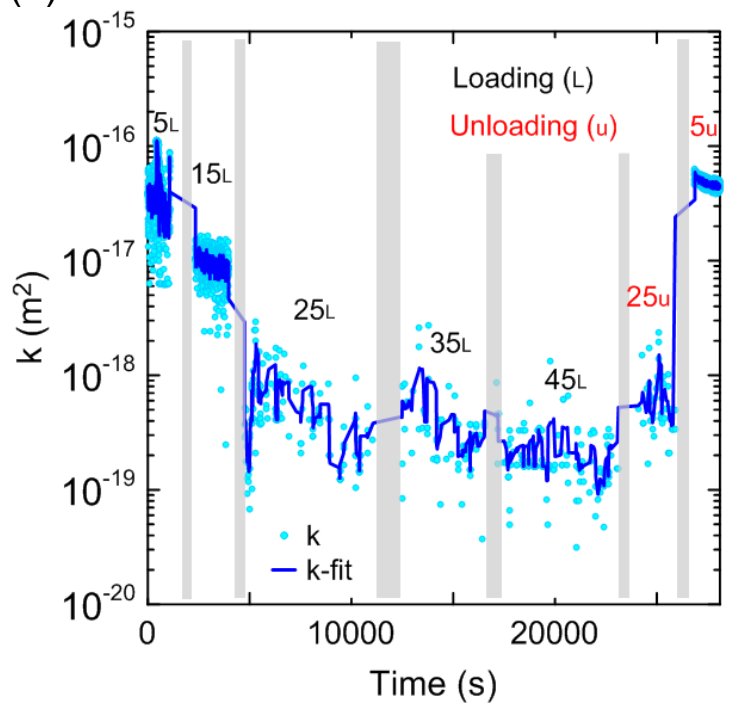

Figure 9. Permeability tests at the different differential stress states, using pore pressure

transmission for (a) S1 and (c) S4, and steady state flow for (b) S2 and (d) S5. Dots are data points; $\mathrm{k}$-fit is running average fitting every 5 points. Labels indicate differential stress (MPa) with subscripts $L$ and $u$ for loading and unloading, respectively. Dark bands in (b) and (d) indicate interludes between two consecutive SSF tests. 


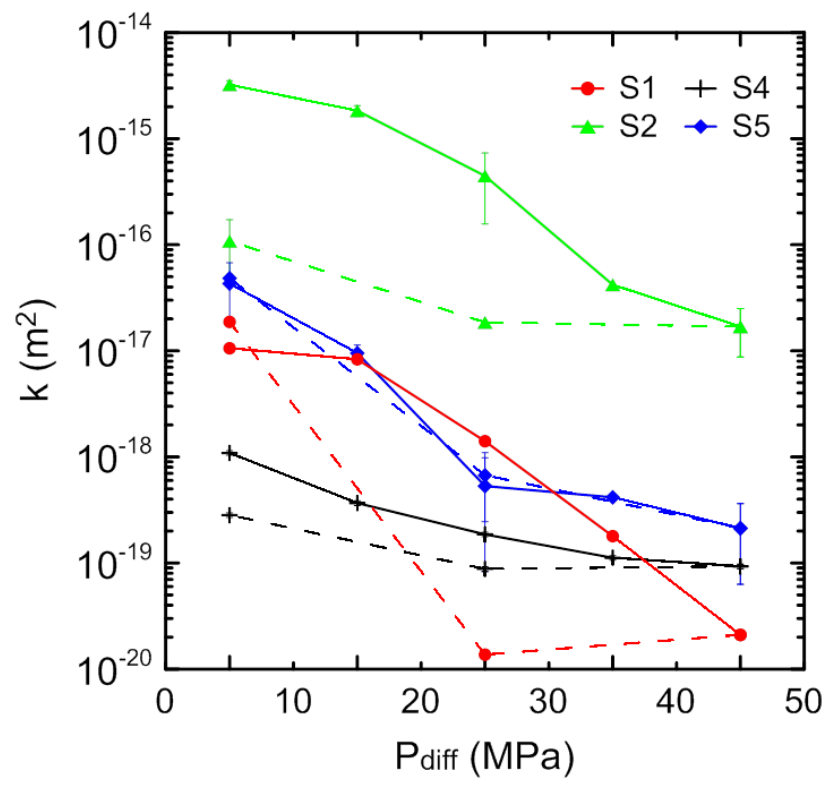

Figure 10. Permeability $(k)$ versus differential stress $\left(P_{\text {diff }}\right)$ for loading (solid line) and unloading (dashed line) stress conditions. 


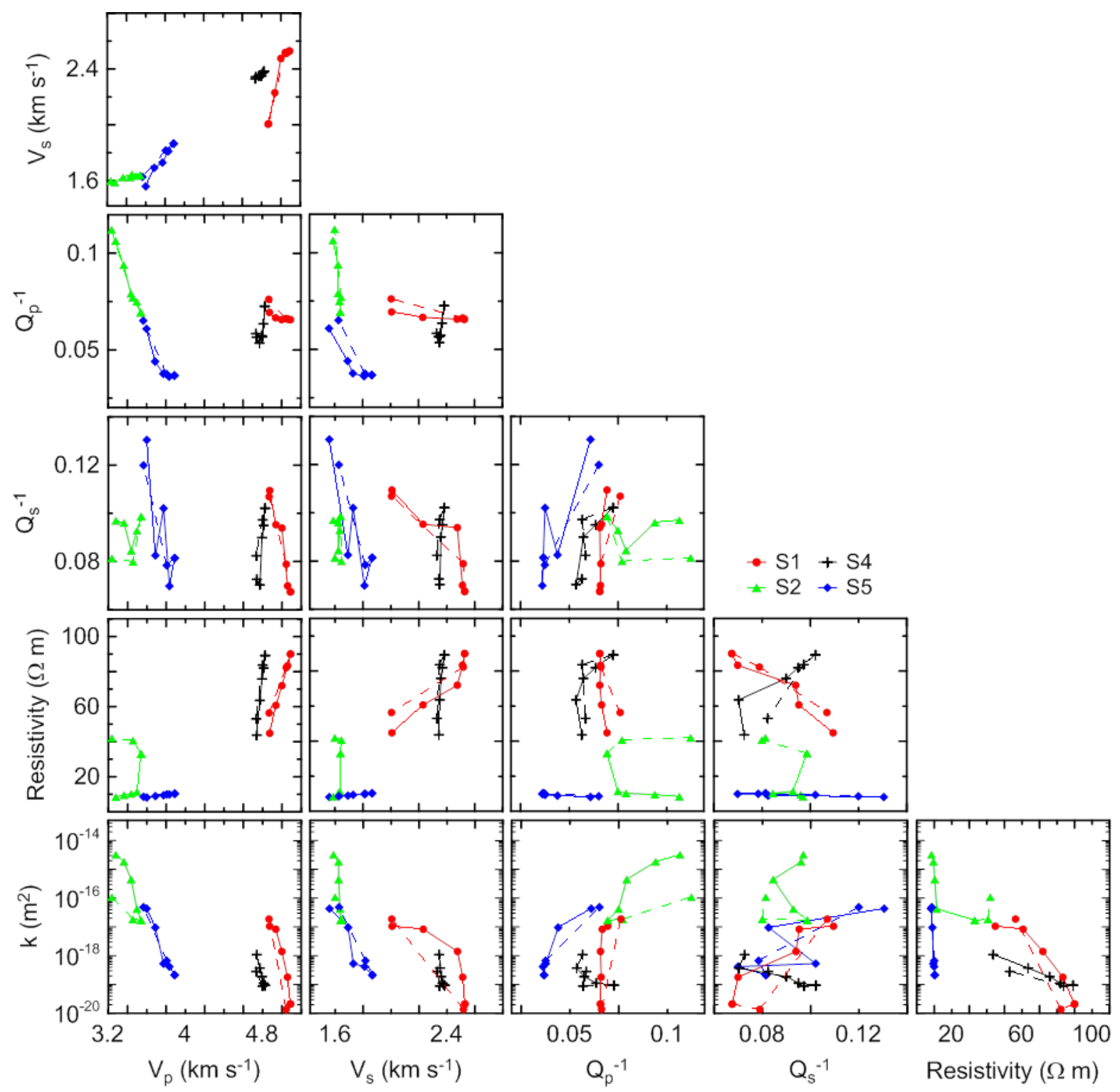

Figure 11. Correlations among measured parameters (ultrasonic wave velocities $V_{p}$ and $V_{s}$, attenuations $Q_{p}{ }^{-1}$ and $Q_{s}{ }^{-1}$, electrical resistivity, and permeability $k$ ) for loading (solid line) and unloading (dashed line) stress conditions. Samples S1, S2, S4 and S5 indicated by different symbols and colours in the key. 


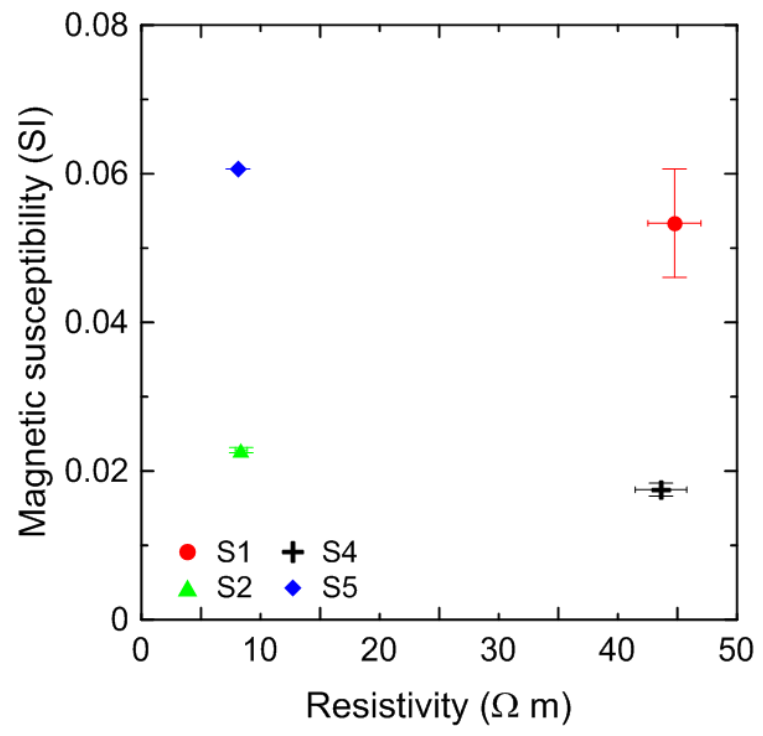

Figure 12. Magnetic susceptibility, measured on the cores during Expedition 357 (FrühGreen et al., 2016) by averaging the nearest points around our samples (Table 1), versus electrical resistivity at $P_{\text {diff }}=5 \mathrm{MPa}$ (i.e., differential pressure that best matches the pressure of the susceptibility measurements). 
(a)

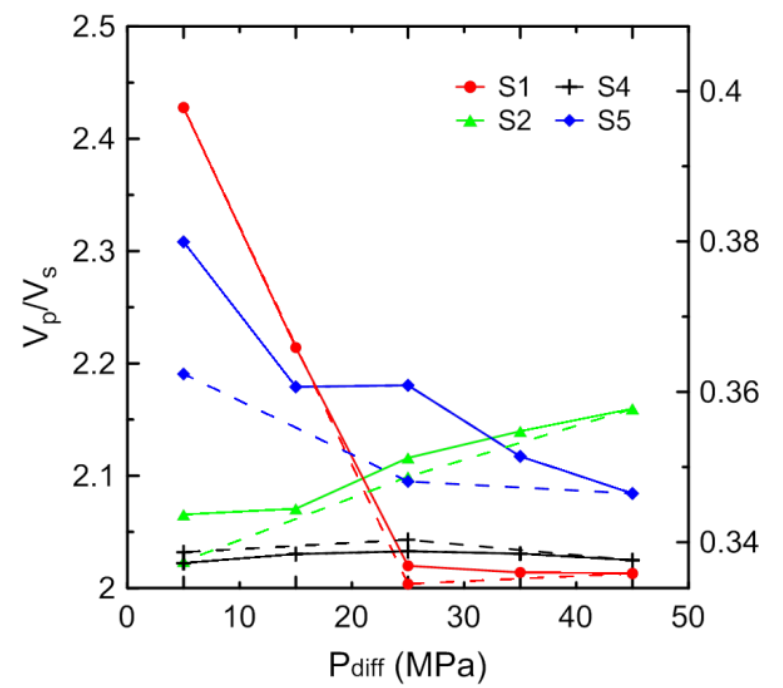

(c)

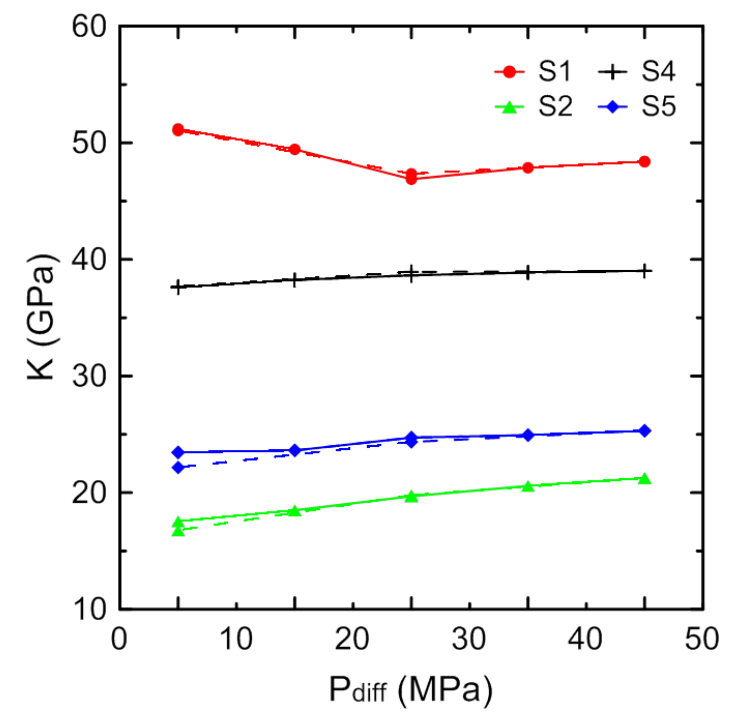

(b)

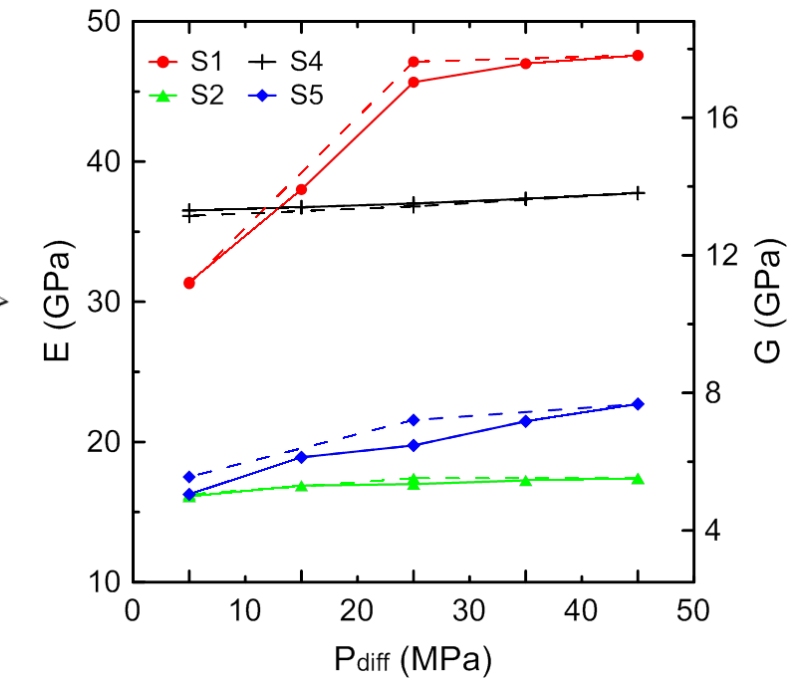

Figure 13. Elastic constants versus differential pressure $\left(P_{\text {diff }}\right)$ : (a) ultrasonic velocity ratio $\left(\mathrm{V}_{\mathrm{p}} / \mathrm{V}_{\mathrm{s}}\right)$ and Poisson's ratio (v); (b) Young's modulus (E) and shear modulus (G); (c) bulk modulus (K). 